\title{
Coastal erosion and mass wasting along the Canadian Beaufort Sea based on annual airborne LiDAR elevation data
}

\author{
Jaroslav Obu ${ }^{\mathrm{a}, *}$, Hugues Lantuit ${ }^{\mathrm{a}, \mathrm{b}}$, Guido Grosse ${ }^{\mathrm{a}}$, Frank Günther ${ }^{\mathrm{a}}$, Torsten Sachs ${ }^{\mathrm{c}}$, Veit Helm ${ }^{\mathrm{d}}$, Michael Fritz ${ }^{\mathrm{a}}$ \\ a Alfred Wegener Institute Helmholtz Centre for Polar and Marine Research, Telegrafenberg A43, 14473 Potsdam, Germany \\ ${ }^{\mathrm{b}}$ University of Potsdam, Am Neuen Palais 10, 14469 Potsdam, Germany \\ c Helmholtz-Centre Potsdam - GFZ German Research Centre for Geosciences, Telegrafenberg, 14473 Potsdam, Germany \\ d Alfred Wegener Institute Helmholtz Centre for Polar and Marine Research, Am Handelshafen 12, 27570 Bremerhaven, Germany
}

\section{A R T I C L E I N F O}

\section{Article history:}

Received 22 March 2015

Received in revised form 9 January 2016

Accepted 17 February 2016

Available online xxxx

\section{Keywords:}

Coastal dynamics

Digital elevation model

Permafrost geomorphology

Retrogressive thaw slump

Yukon coast

Beach dynamics

\begin{abstract}
A B S T R A C T
Erosion of permafrost coasts has received increasing scientific attention since 1990s because of rapid land loss and the mobilisation potential of old organic carbon. The majority of permafrost coastal erosion studies are limited to time periods from a few years to decades. Most of these studies emphasize the spatial variability of coastal erosion, but the intensity of inter-annual variations, including intermediate coastal aggradation, remains poorly documented. We used repeat airborne Light Detection And Ranging (LiDAR) elevation data from 2012 and 2013 with $1 \mathrm{~m}$ horizontal resolution to study coastal erosion and accompanying mass-wasting processes in the hinterland. Study sites were selected to include different morphologies along the coast of the Yukon Coastal Plain and on Herschel Island. We studied elevation and volume changes and coastline movement and compared the results between geomorphic units. Results showed simple uniform coastal erosion from low coasts (up to $10 \mathrm{~m}$ height) and a highly diverse erosion pattern along coasts with higher backshore elevation. This variability was particularly pronounced in the case of active retrogressive thaw slumps, which can decrease coastal erosion or even cause temporary progradation by sediment release. Most of the extremes were recorded in study sites with active slumping (e.g. $22 \mathrm{~m}$ of coastline retreat and $42 \mathrm{~m}$ of coastline progradation). Coastline progradation also resulted from the accumulation of slope collapse material. These occasional events can significantly affect the coastline position on a specific date and can affect coastal retreat rates as estimated in long term by coastline digitalisation from air photos and satellite imagery. These deficiencies can be overcome by short-term airborne LiDAR measurements, which provide detailed and high-resolution information about quickly changing elevations in coastal areas.
\end{abstract}

(c) 2016 Elsevier B.V. All rights reserved.

\section{Introduction}

About $34 \%$ of the Earth's coasts are affected by permafrost; $35 \%$ of these coasts in the Arctic are lithified, while 65\% are unlithified (Lantuit et al., 2012) and particularly vulnerable to coastal erosion. Where excess ground ice is present, coastal erosion is especially efficient because of the thermal impact of sea water and the loss of volume upon thaw. Permafrost coastal erosion is limited to the ice-free summer season and is during this period comparable to rates of rapidly eroding non-Arctic coasts (Are, 1988). An average Arctic coastal erosion rate is $0.5 \mathrm{~m} \mathrm{a}^{-1} ; 3 \%$ of the Arctic coastline is retreating faster than $3 \mathrm{~m} \mathrm{a}^{-1}$. (Lantuit et al., 2012). Jones et al. (2009) reported an extreme 25 m erosion event that occurred during one year at Drew Point, a particularly ice-rich site on the Alaskan Beaufort Sea coast. Permafrost coastal erosion has attracted much scientific attention because of the large amounts of sediment released to the Arctic Ocean (Rachold et al.,

\footnotetext{
* Corresponding author.

E-mail address: jaroslav.obu@awi.de (J. Obu).
}

2000), the mobilisation of old organic carbon (Vonk et al., 2012), and the release of nutrients which affects elemental budgets and biogeochemical cycles in the coastal zones of the Arctic Ocean (Ping et al., 2011).

High erosion rates can occur within a short time period at specific locations (Dallimore et al., 1996; Barnhart et al., 2014a), while average erosion rates for longer coastal segments or long observation periods are generally much lower (Solomon, 2005). This spatial and temporal variability is caused by a wide spectrum of factors acting at different spatio-temporal scales. Regional factors acting on a larger scale are storminess, waves and storm surges, ice-free season duration, sea level, and summertime sea surface temperature. Local factors controlling erosion are sediment properties (cohesiveness and grain size), cryostratigraphy (amount, type, and distribution of ground ice), and geomorphology (cliff height and slope, exposure, underwater shore slope, presence of barrier islands and spits, littoral sediment supply, and coastal hinterland topography) (Héquette and Barnes, 1990; Solomon, 2005; Jones et al., 2009). Dallimore et al. (1996) emphasised the importance of storm events in connection with ground ice contents 
in the onshore sediments for coastal erosion in the Canadian Beaufort Sea. Barnhart et al. (2014a) indicated the importance of the sea-icefree season, wave exposure, and sea water temperature in the Alaskan Beaufort Sea, while Günther et al. (2015) demonstrated the importance of the temporal concurrence of open water with warm summer air temperatures in the southern Laptev Sea.

Arctic coastal erosion studies commonly use historic and current satellite imagery or aerial photographs to define coastlines position based on ocean-land interface. This approach provides horizontal measures of coastal retreat. Timespans between different datasets using this method usually ranged from 50 to 10 years, the shortest being 5 years in Jones et al. (2009). Studies that attempted to quantify volumetric change used digital elevation models (DEMs) derived from tacheometric surveys (on shorter timespans) and stereophotogrammetry (on longer timespans) (Lantuit and Pollard, 2005; Leibman et al., 2008; Günther et al., 2012, 2015). In contrast to the methods used in these studies, airborne Light Detection And Ranging (LiDAR) scanning enables short term mapping of small objects and surfaces with very little texture and contrast and offers new applications for coastal erosion studies. White and Wang (2003) and Young and Ashford (2006) used repeat airborne LiDAR data to estimate volumetric erosion and sediment pathways of non-permafrost coasts. Jones et al. (2013) demonstrated suitability of airborne LIDAR data for landscape changes of arctic coastal lowlands, including volumetric changes due to coastal erosion.

Most existing studies on permafrost coastal erosion estimate the erosion rates over time periods from a few years to decades. Many of the factors influencing coastal erosion are discrete events in time and space and can significantly vary between years. Examples are different mass-wasting processes such as retrogressive thaw slumping, activelayer detachments and block failures, which are typical for ice-rich and unconsolidated coasts. Retrogressive thaw slumping is a very rapid mass wasting formed by thaw of ice-rich ground (Lantz and Kokelj, 2008). Retreat of exposed massive ice on sloping terrain leads to the formation of C-shaped depressions surrounded by a headwall (Burn and Lewkowicz, 1990; Lantuit and Pollard, 2008). Retrogressive thaw slumps (RTSs) can transport considerable amounts of sediments in form of earth falls and mudflows (Lantuit and Pollard, 2005). Active-layer detachment (ALD) is a translational landslide with a shallow failure plane that occurs on very gentle to moderate slopes in summer-thawed material overlying permafrost (Lewkowicz and Harris, 2005). Block failure is a very rapid form of mass wasting along permafrost coasts, which involves the collapse of large blocks that detach from cliffs under the influence of gravity. The collapsed blocks have to be first removed before coastal erosion can proceed (Hoque and Pollard, 2009). These geomorphic processes cannot be recorded by long-term datasets, because the evidence of their occurrence is lost due to other processes acting on the coast. For this reason the influence of mass-wasting processes and consequent sediment release on the erosion of unconsolidated permafrost coasts remains poorly and partially understood.

The aim of this study is to characterise short-term coastal erosion and relate it to geomorphic processes in the immediate coastal hinterland based on repeat LiDAR DEM datasets from 2012 to 2013 for various segments of the Canadian Beaufort Sea coast. Our objectives are to (1) quantify the magnitude and spatial patterns of coastal erosion and volumetric changes for a one-year period, (2) explore the coastal change in different geomorphic units and relate it to mass-wasting associated geomorphic processes.

\section{Study area}

The Yukon Coastal Plain (Canada) is characterised by active coastal erosion and an abundance of mass wasting processes. It is situated between the Mackenzie Delta to the east and the Alaskan border to the west, and extends north of the British and Richardson mountains towards the Beaufort Sea. Its coastline is approximately $280 \mathrm{~km}$ long.
East of the Firth River the area was glaciated from an east by an extension of the Laurentide Ice Sheet (Fig. 1) (Mackay, 1959; Hughes, 1972). Much of the area within the maximum glacial limit is covered by moraines. Herschel Island was formed as an ice-thrust moraine (Mackay, 1959). Glacial sediments were reworked by thermokarst processes and other surficial sediments are of lacustrine, fluvial, or glaciofluvial origin (Rampton, 1982). The sediment composition ranges from organic fine-grained mixtures of clay, silt, and sand in lacustrine deposits to fine-grained marine deposits and tills with pebbles and cobbles in moraines (Bouchard, 1974; Rampton, 1982; Fritz et al., 2012). These sediments are commonly unconsolidated with considerable amounts of ground ice ranging from 30 to 60 volume percent (Couture, 2010). Ice wedges, segregated ice, and massive ice are common and lead to the occurrence of thermokarst landforms. Where massive ground ice occurs along the coast, retrogressive thaw slumps (RTSs) actively develop (Lantuit and Pollard, 2005).

The backshore elevations range from a few meters to $30 \mathrm{~m}$ and do not exceed $50 \mathrm{~m}$ except at Kay point, where the elevation reaches $80 \mathrm{~m}$, and on Herschel Island where it exceeds $100 \mathrm{~m}$. The coast is mostly erosional, with steep bluffs, except where it is protected by barrier islands, spits, and beaches; these landforms mostly occur where there is riverine material supply or strong longshore drift, as is the case between Catton Point and Komakuk Beach (Fig. 1). Mass wasting can be locally very active and RTSs, ALDs and block failures can occur on the same site.

The polar climate of Yukon Coast has a pronounced continental character in winter and maritime influences in summer during the open-water season (Wahl et al., 1987). The mean annual air temperature $(1971-2000)$ is $-11.0{ }^{\circ} \mathrm{C}$ at Komakuk Beach, the closest weather station $\sim 40 \mathrm{~km}$ west of Herschel Island, with an average July maximum of $7.8^{\circ} \mathrm{C}$ (Environment Canada, 2015). Mean annual precipitation is between $161 \mathrm{~mm} \mathrm{a}^{-1}$ at Komakuk Beach and $254 \mathrm{~mm} \mathrm{a}^{-1}$ at Shingle Point ( $100 \mathrm{~km}$ southeast of Herschel Island) and is almost equally apportioned between rain and snow (Environment Canada, 2015).

Storms, which are frequent in late August and September, come predominantly out of the west and northwest, with a secondary mode from the east to the southeast (Hudak and Young, 2002; Solomon, 2005). Winds blowing over open waters can generate significant wave heights of $4 \mathrm{~m}$ or more (Pinchin et al., 1985). The coastal areas of the Beaufort Sea are ice-covered for 8-9 months of the year, with complete sea-ice cover from mid-October through June (Solomon, 2005). The recent trend of open water season lengthening around Herschel Island is 1.5 day $^{-1}$ (Barnhart et al., 2014b). Sea ice is usually shorefast to depths $<2 \mathrm{~m}$ (Solomon et al., 1994).

Coastal erosion is particularly active during the storms that occur in the ice-free season Atkinson (2005). The study area was, according to MODIS imagery (NASA EOSDIS, 2015), land-fast ice free between June 28 and October 31 in 2012 and the land-fast ice breakup in 2013 was on June 21. Between ice breakup in 2012 and the second data acquisition (see next section), there were 10 storm events (wind speeds exceeded $10 \mathrm{~ms}^{-1}$ for at least $6 \mathrm{~h}$ ) recorded (Environment Canada, 2015). All storms generated north-westerly winds (between 300 and $340^{\circ}$ direction) and the majority of the storms occurred in September and October. Consequently, the north and west coasts of Herschel Island were the most exposed to storm waves.

\section{Methods}

\subsection{Airborne LiDAR data}

LiDAR scanning of the Yukon Coast and Herschel Island took place during the AIRMETH (AIRborne studies of METHane emissions from Arctic wetlands) campaigns (Kohnert et al., 2014) on 10 July 2012 and on 22 July 2013. Point cloud data were acquired with a RIEGL LMSVQ580 laser scanner instrument on board the Alfred Wegener 


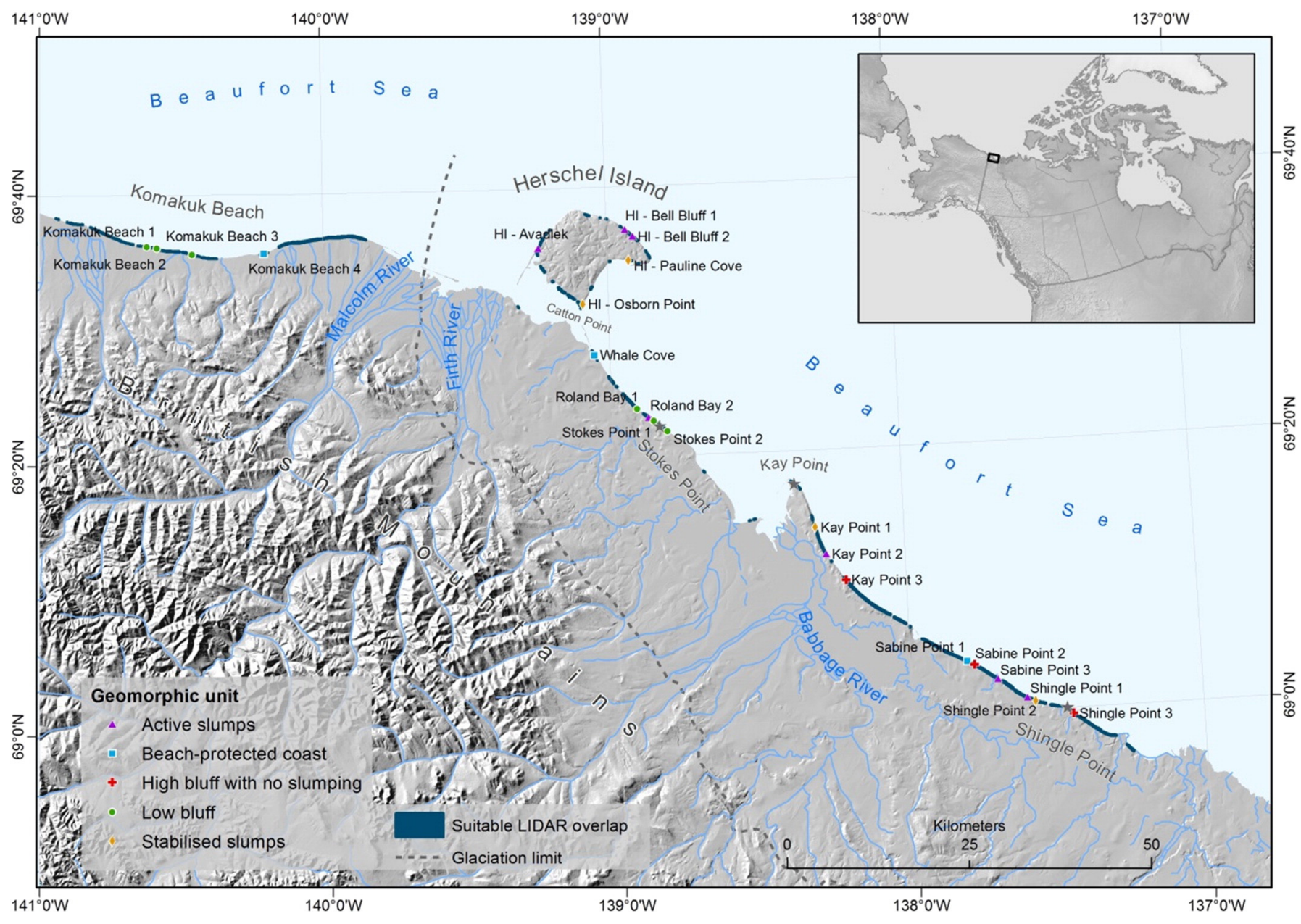

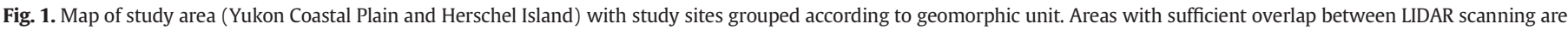

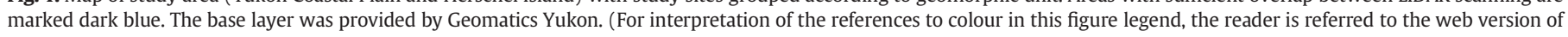
this article.)

Institute's POLAR-5 science aircraft. The laser scanner was operated with a $60^{\circ}$ scan angle at a flight height of around $200 \mathrm{~m}$ above ground in 2012 and $500 \mathrm{~m}$ in 2013. This resulted in a scan width from 200

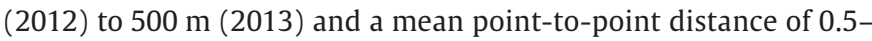
$1.0 \mathrm{~m}$. During the flight on July 10, 2012 the weather was cloudy with a cloud base around 200 m.a.s.l. Air temperature ranged between 10 and $12{ }^{\circ} \mathrm{C}$ with wind speed ranging from 15 to $19 \mathrm{~km} / \mathrm{h}$ from easterly direction $\left(70-90^{\circ}\right)$. The last recorded storm was on June 17. During the scanning on July 22, 2013, the weather was nearly cloudless with air temperature $9{ }^{\circ} \mathrm{C}$. Wind speed was $15 \mathrm{~km} / \mathrm{h}$ from easterly direction $\left(60-80^{\circ}\right)$. The last storm before the acquisition occurred on July 2.

Raw laser data were calibrated, combined with the post-processed GPS trajectory, corrected for altitude, and referenced to the EGM (Earth Gravitational Model) 2008 geoid (Pavlis et al., 2008). The final georeferenced point cloud data accuracy was determined to be better than $0.15 \pm 0.1 \mathrm{~m}$. The loss of accuracy varied along the flight track because of the vertical accuracy of the post-processed GPS trajectory. The GPS data were acquired in $50 \mathrm{~Hz}$ resolution with a Novatel OEM4 receiver on board POLAR-5. The GPS trajectory was post-processed using precise ephemerides and the commercial software package Waypoint 8.5 (PPP [precise point positioning] processing). For the interpolation to the final DEM an inverse distance weighting (IDW) algorithm was applied using all cloud points within a 10 m radius of each point. Finally, the DEMs from the different acquisition years were interpolated to raster grids of $1 \mathrm{~m}$ horizontal resolution in NAD83 UTM zone 7 coordinate system (Fig. 2).

To quantify vertical change that is significant at the $99 \%$ confidence interval, we used three times RMS error procedure by Jaw (2001). A threshold that describes elevation change between both datasets was calculated using the equation:

threshold $=3 \times \sqrt{(2012 \text { vertical accuracy })^{2}+(2013 \text { vertical accuracy })^{2}}$

Vertical accuracies for both datasets were estimated to be $0.15 \mathrm{~m}$, which results in the threshold of $0.64 \mathrm{~m}$ for significant vertical elevation change.

The accuracy of the datasets was additionally tested at locations characterised by the presence of anthropogenic features that presumably remain stable and are not affected by vertical movements because of artificial embankments underneath them (Fig. 3). The first feature was a gravel road near an oil tank facility at Shingle Point. The second feature was an airstrip at Stokes Point on beach accumulation features which are unlikely to be underlain by near-surface ice-rich permafrost (Smith et al., 1989). The differences between both DEM datasets were assessed along profiles and were within the previously-stated $0.15 \mathrm{~m}$ uncertainty. (See Fig. 4.) 

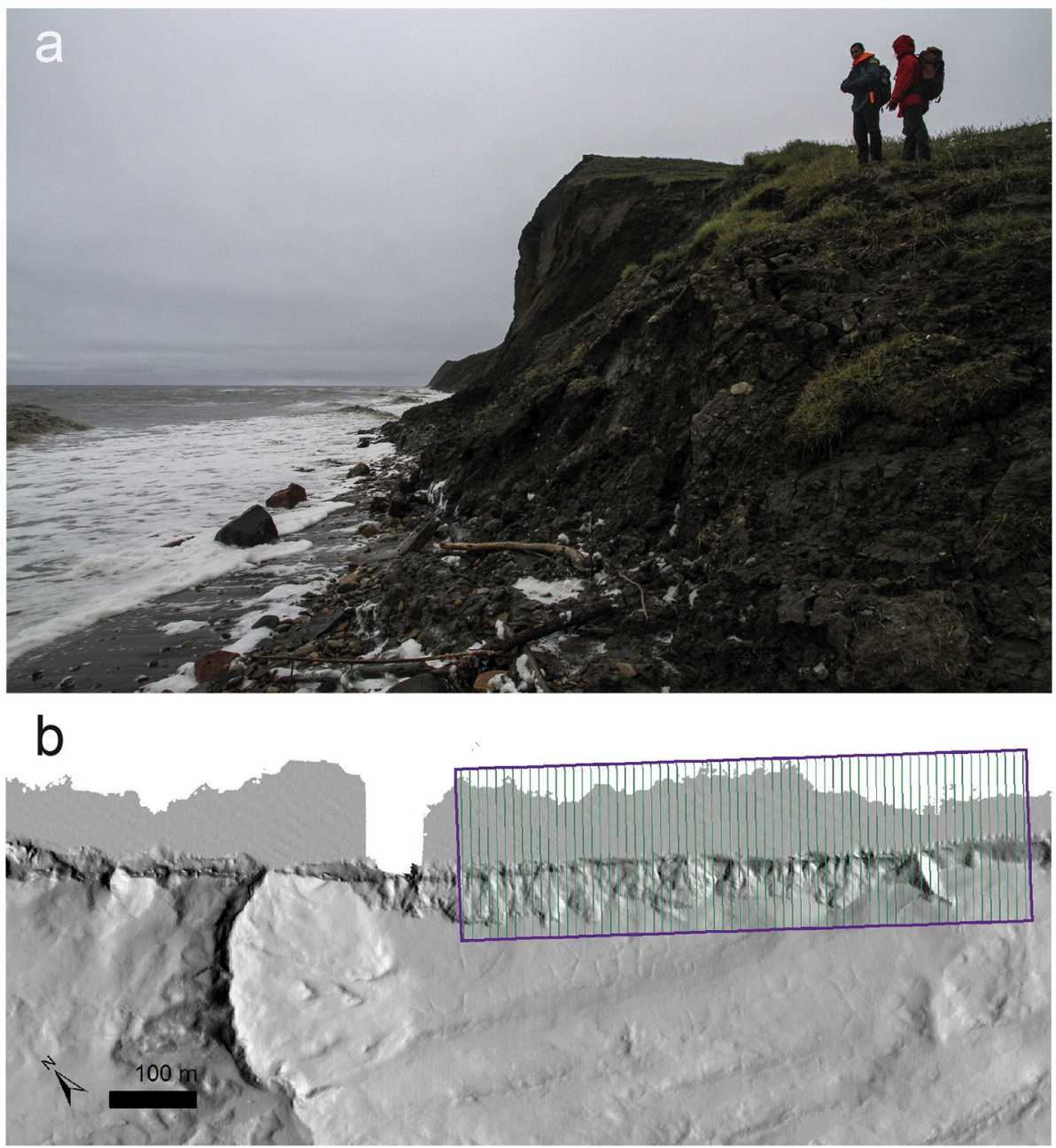

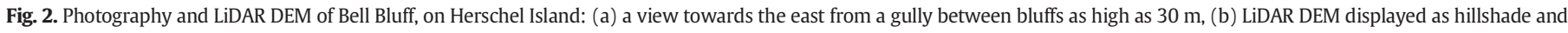
transects perpendicular to the coastline with $10 \mathrm{~m}$ spacing at the Bell Bluff 2 study site.

\subsection{Study sites selection and classification}

Study sites were chosen along the Yukon Coast and Herschel Island so that all major geomorphologic coastal types were represented. Different mass-wasting processes frequently occur together in our study area and for this reason we use the term slumping for all mass wasting, ranging from very-small-scale mass movement features as ALDs to major RTSs and rapid slope collapses. Typical block failures as reported by Hoque and Pollard (2009) were not observed during our study period. Only small turf collapses were observed in low bluffs. We defined stabilised slumps where there was an evidence of past but currently inactive slumping. Slumping, bluff height, and presence of beach were the main criteria for classification. To include all prevalent geomorphic processes we classified sites as low bluffs, active slumps, stabilised slumps, high bluffs with no slumping, or beach-protected coasts (Table 1 ). A beach was defined according to Bird (2011) as "an accumulation on the shore of generally loose and unconsolidated sediment" that we observed from elevation data. There was little or no evidence of slumping on bluffs lower than $10 \mathrm{~m}$ so only coastal bluffs higher than $10 \mathrm{~m}$ were classified as active or stabilised slumps. Altogether, 23 coastal sections from 200 to $500 \mathrm{~m}$ length and $200-250 \mathrm{~m}$ width were chosen as study sites (Table 2, Fig. 1). Barrier islands, spits, and other depositional features were not included in the study because annual change rate was usually too low to be observed by our dataset.

\subsection{Quantification of erosion rates and volume change}

We created metrics of coastal dynamics using the elevation models derived from the LiDAR data. These indicators included elevation change, volume change, coastline movement, and hinterland erosion length. We then distinguished between erosion and progradation change for the first three indicators. For erosion, changes were termed elevation decrease, volume decrease, and coastline retreat. For progradation, changes were termed elevation increase, volume increase, and coastline progradation (for details see next paragraph). We also report an area over which elevation increase and decrease occurred in each study site. The 2012 elevation dataset was subtracted from the 2013 dataset to calculate the elevation difference. The observation period was one year and 12 days; thus, the values presented in this paper overestimate yearly rates by $3 \%$. Only elevation changes greater than the uncertainty threshold $(0.64 \mathrm{~m})$ were included in the analyses. All elevation changes that were caused by changes in water surfaces (e.g. sea waves) between the two data acquisitions were excluded from further analyses. Indicators were separately calculated for each study site and for each geomorphic unit using the raw data of all sites in the unit (Table 2, Fig. 5).

Descriptive statistics on elevation change and volume change were calculated from pixels within the extent of the study site. Values were calculated separately for elevation decrease and elevation increase with ArcGIS 10.1. We calculated volume decrease in 

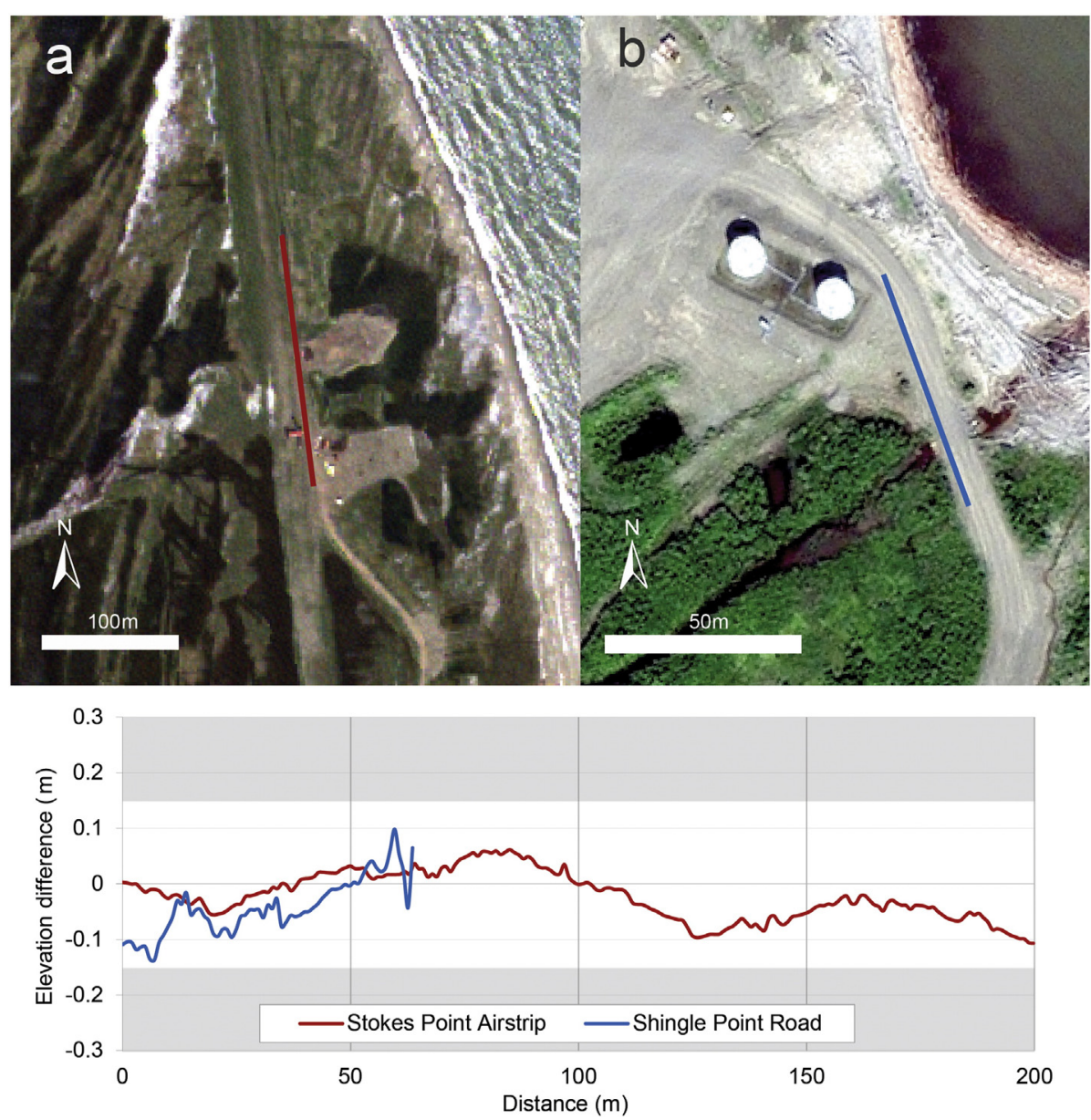

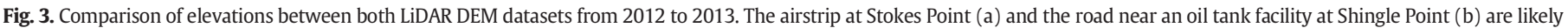

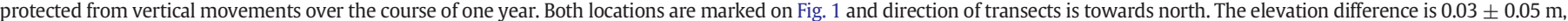
inside the $\pm 0.15 \mathrm{~m}$ elevation uncertainty stated for the entire dataset.

$\mathrm{m}^{3}$ as the sum of elevation decrease of pixels within the extent of the study site. The same procedure was separately applied for volume increase. Volume change was then normalised to $100 \mathrm{~m}$ of coast to allow comparison among the sites and with other studies. The exact extent of RTSs was digitised in the Roland Bay 2, Kay Point 2,
Sabine Point 3, and Shingle Point 1 units. Volume change properties were calculated separately for these RTSs to highlight their volume change characteristics.

Coastline movements and hinterland erosion length were calculated using parallel transects with $10 \mathrm{~m}$ spacing stretching across the entire
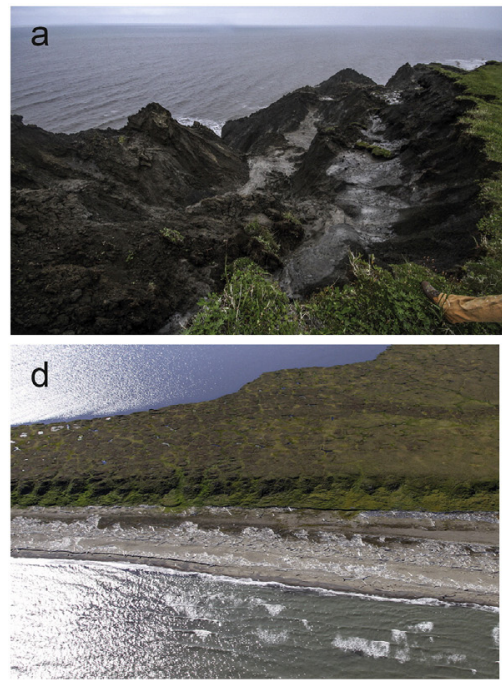
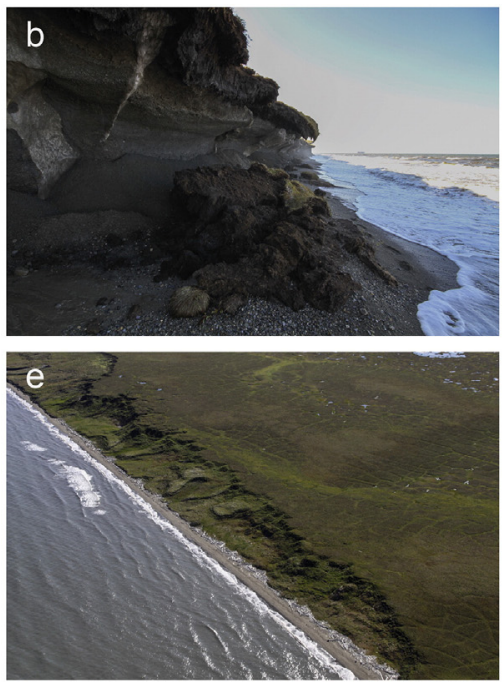

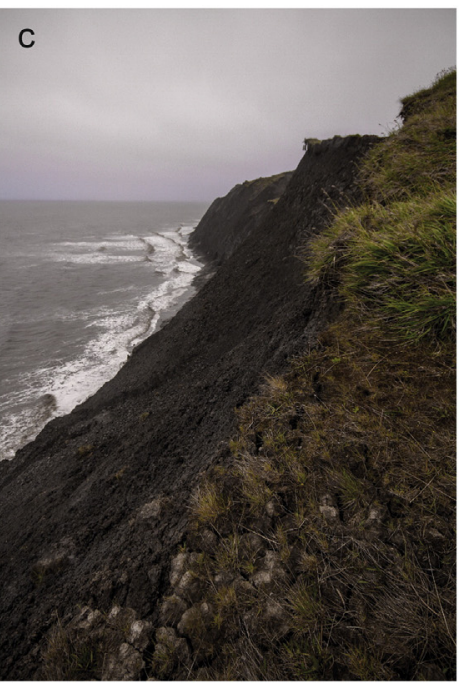

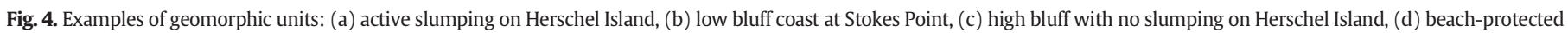
coast at Stokes Point and (e) stabilised slumps in Roland Bay. 


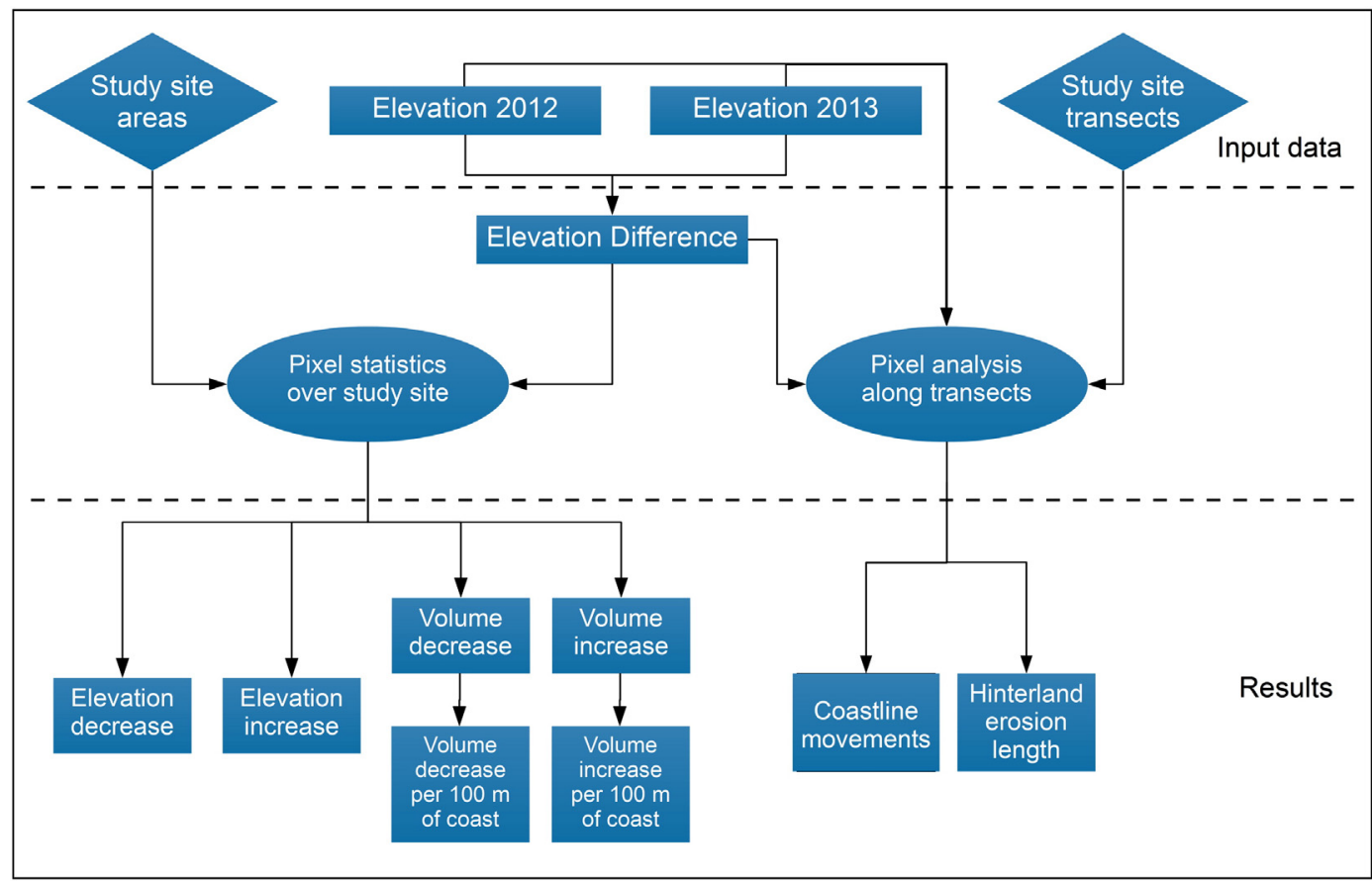

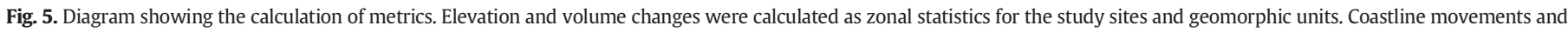
hinterland erosion length were calculated from elevation changes along transects in the study sites.

study site perpendicular to the coast. Every pixel of the DEM difference raster was analysed along these transects. Values along each transect were extracted in ArcGIS 10.1 from the elevation difference dataset and from both the 2012 and 2013 elevation datasets, and then analysed using R software (version 3.0.1). The coastline was defined according to Bird (2011) as "the edge of the land at the limit of normal high spring tides". Reported high spring tide range in our area (Tuktuyaktuk station) is no more than $0.5 \mathrm{~m}$ (Canadian Hydrographic Service, 2015). To take into account both tidal range and dataset uncertainty, we defined coastline as the $1 \mathrm{~m}$ contour of the DEM. Coastline movement along transects was calculated as the distance between the coastline positions in 2012 and 2013. Hinterland erosion indicates how far inland the effect of coastal erosion stretched. This parameter is meant to encompass the erosional processes acting upon the lower part of the cliff and the mass-wasting processes acting on its upper part. We defined hinterland erosion as the maximum continuous length along a transect that underwent elevation decrease during the study period.

\section{Results}

We analysed coastline and backshore areas over a total coast length of $10.2 \mathrm{~km}$ (out of $96 \mathrm{~km}$ of suitable data) and classified the coast into five geomorphic units. Among them, 33\% belonged to the unit of active slumps, $23 \%$ to low bluffs, $19 \%$ to stabilised slumps, $13 \%$ were high bluffs with no slumping, and $12 \%$ belonged to the unit of beach-protected coasts. The percentage of coastline length (percentage of transects) affected by coastal erosion was $78 \%$. The studied coastal site areas were mostly affected by elevation decrease (76\%), while a smaller portion was affected by elevation increase (24\%). The most extensive elevation decrease occurred in the active-slumps geomorphic unit $(13.2 \%$ of coastal area). The elevation of beach-protected coasts was relatively stable; only small areas were affected by elevation decrease $(1.5 \%)$ or increase (5.1\%).

\subsection{Elevation and volume changes}

The maximum elevation decrease was recorded in an active-slumps unit (18.6 m, Sabine Point 3) but this coastal type also showed strong elevation increase (9.1 m, Bell Bluff 1 ) where the eroded material was re-deposited from slope collapse (Tables 3 and 4). A high mean elevation decrease was recorded in the active-slumps and high-bluffs units (3.1 and $3.0 \mathrm{~m}$, respectively). Mean elevation decrease was lower in the three other units (1.1-1.8 $\mathrm{m}$ ). The highest volume decreases were observed in the active-slumps unit, followed by low bluff, high bluff with no slumping, stabilised slumps, and beach-protected coast. The volume decrease in active slumps was two times larger than in the low-bluff unit and three times larger than in stabilised slumps. The largest positive volume changes (i.e. volume increase) were observed in beach-protected coasts and stabilised slumps followed by active slumps, while low bluffs underwent the lowest volume accumulation. The only unit where volume increase was greater than decrease was beach-protected coasts. The distribution of elevation change varies greatly between the sites (Figs. 6, 7, 8, and 9). Strict areas of RTSs alone (delineated with dark blue line on Figs. 7 and 8) were characterised by a volume decrease of $117554 \mathrm{~m}^{3}$ and a volume increase of $6480 \mathrm{~m}^{3}$, meaning that $5.5 \%$ of mobilised material reaccumulated.

\subsection{Coastline movements}

Both coastline retreat and progradation occurred along the studied transects regardless of geomorphic unit (Tables 5 and 6). Mean coastline movement was $0.1 \pm 9.0 \mathrm{~m}$, while the median exhibits no net coastline movement. Coastal retreat was prevalent along low bluffs and stabilised slumps with a mean retreat of $4.5 \mathrm{~m}$ and $2.6 \mathrm{~m}$, respectively. Progradation was observed along beach-protected coasts ( $5.2 \mathrm{~m})$, active slumps (2.2 $\mathrm{m})$, and high bluffs with no slumping $(1.7 \mathrm{~m})$. The mean progradation for the active-slumps unit was greatly affected by the values from the Sabine Point 3 site. Mean retreat of $0.8 \mathrm{~m}$ was observed for the other six active-slump sites. Relatively high standard deviations (Table 6) and non-normal distribution of variables (Fig. 10) show that extreme values significantly influenced the averages. The maximum coastline retreat and progradation occurred in the active-slumps unit (22 $\mathrm{m}$ and $42 \mathrm{~m}$, respectively). High maximum retreat rates occurred in the low-bluff unit $(21 \mathrm{~m})$ and along coasts with stabilised slumps $(17 \mathrm{~m})$. The second highest progradation was recorded in the beach- 

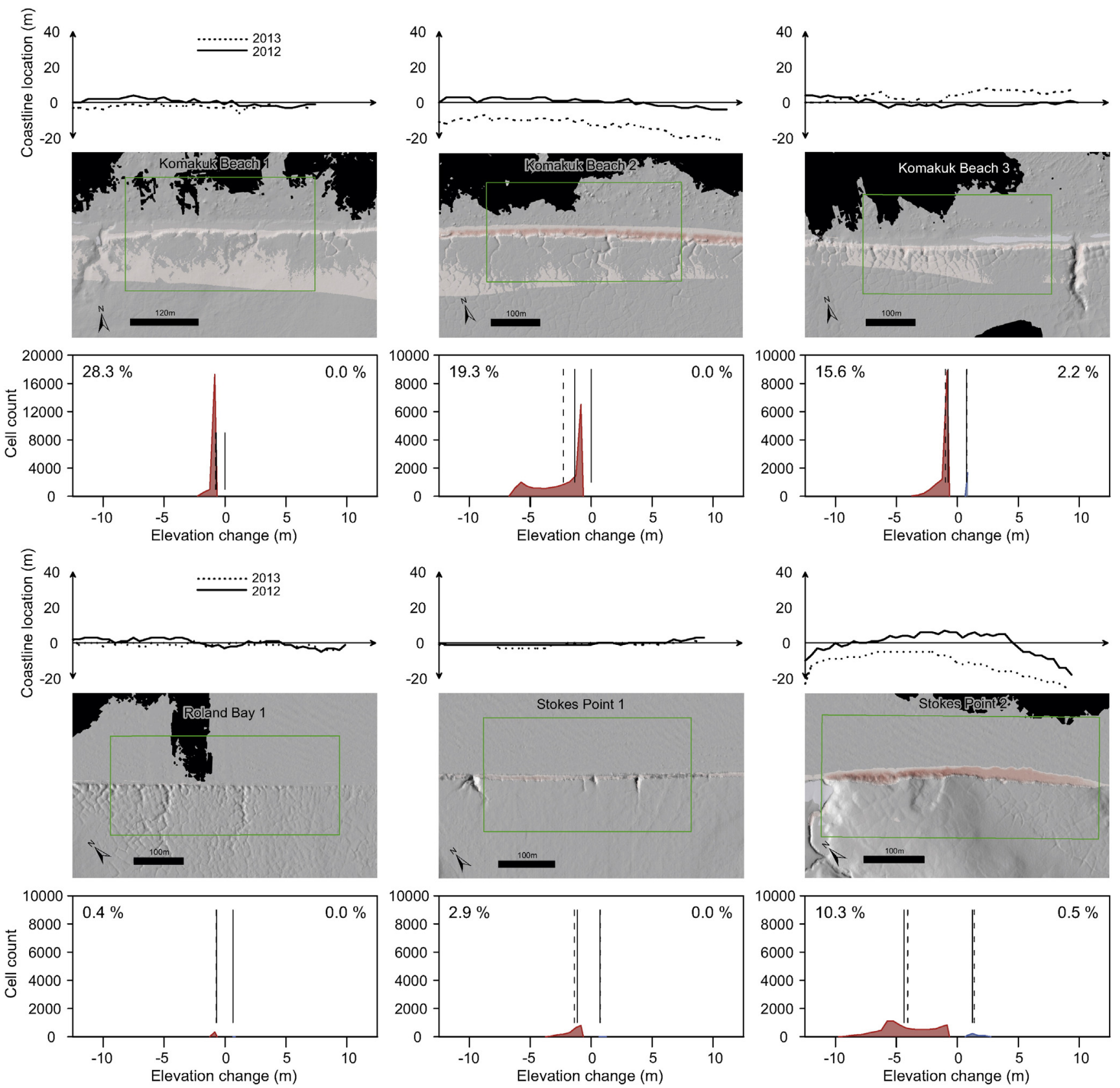

Elevation change $(\mathrm{m})$

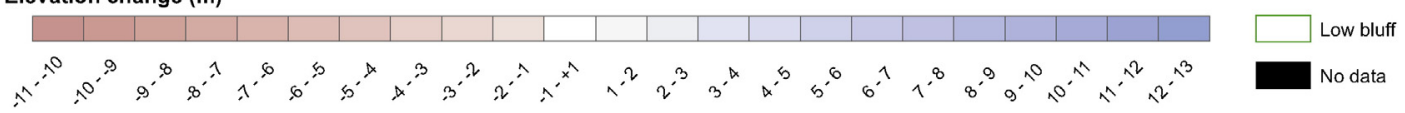

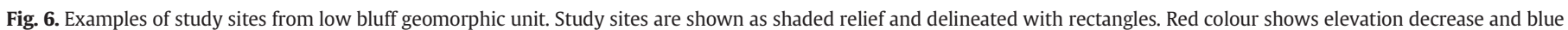

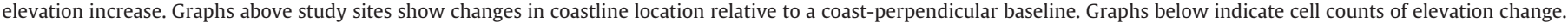

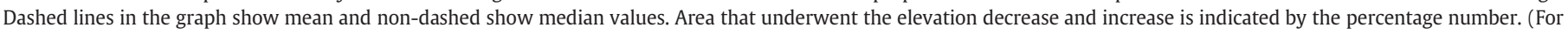
interpretation of the references to color in this figure legend, the reader is referred to the web version of this article.)

protected coast unit. Hinterland erosion was greater in active slumps, low bluffs, and stabilised slumps (hinterland erosion length was around or above $20 \mathrm{~m}$ ) and less in high bluffs with no slumping and beachprotected coasts. The effects of coastal erosion stretched $15.8 \pm$ $15.8 \mathrm{~m}$ inland, on average, across all sites.

\section{Discussion}

This study provides insights into the spatial erosion variability related to geomorphic processes in the Canadian Beaufort Sea on the temporal scale of 1 year. High variability of coastal erosion intensity between different geomorphic units and also within study sites suggests that, even at a local scale, coastal erosion processes were highly heterogeneous. We attribute some of the variability to different mass-wasting processes in the hinterland along the coast.

\subsection{Coastal erosion and its variability}

The maximum coastline retreat rate of $22 \mathrm{~m}$ that was recorded on Herschel Island is in the range of extreme erosion rates that were reported in unconsolidated and ice-rich coasts from other investigations in the Canadian and Alaskan Beaufort Sea and from the Laptev Sea 

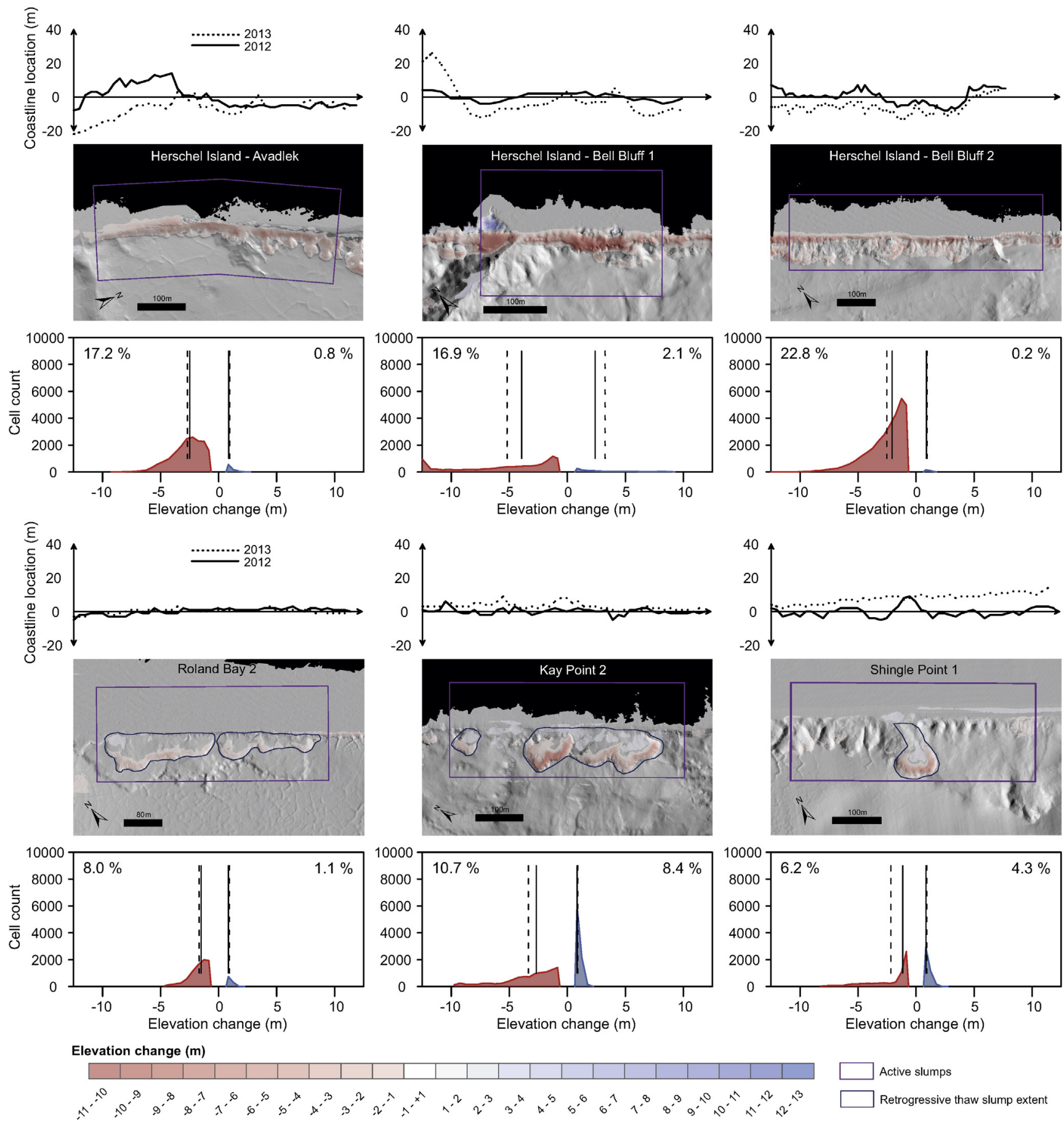

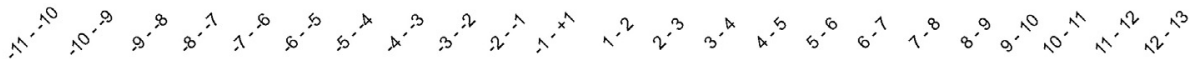

Retrogressive thaw slump extent

Fig. 7. Examples of study sites from active slumps geomorphic unit. RTS extents used for separate volume calculation are delineated with blue line.

region (Solomon, 2005; Jones et al., 2009; Günther et al., 2013). Maximum coastline progradation was $42 \mathrm{~m}$ and was a consequence of beach progradation by the material delivered from an RTS (Fig. 8, Sabine Point 3). A high progradation of up to $20 \mathrm{~m}$ was observed on Herschel Island (Fig. 7, Bell Bluff 1), where material accumulated from rapid slope collapse. Comparable progradation rates were not yet documented by other studies in similar environment. Solomon (2005) reported local variations up to $17 \mathrm{~m} \mathrm{a}^{-1}$ of coastline retreat and progradation rates up to only $7 \mathrm{~m}$ in the Mackenzie Delta region (for period 19722000). We observed high coastline movement temporal variability of $11.0 \pm 3.3 \mathrm{~m}$ at the Shingle Point 2 site, but Hynes et al. (2014) recorded coastline movement rates between $0.6 \mathrm{~m} \mathrm{a}^{-1}$ and $-0.3 \mathrm{~m} \mathrm{a}^{-1}$ between
1953 and 2004. Higher short-term variability is indicating that coastal erosion and accumulation occur in episodic events with similar characteristics that Sadler (1981) observed for sediment accumulation records in sedimentary rocks.

Our results show (Table 6, Fig. 5) that not only coastline movements but also volume changes are very spatially heterogeneous. High volume losses do not always coincide with coastline retreat. Considerable volume losses occurred at the Shingle Point 1 and Sabine Point 3 sites despite high coastline progradation. Elevation decreases of more than $10 \mathrm{~m}$ were recorded at sites with active erosion and mass-wasting processes at high backshore elevations. High variability of hinterland erosion $(15.8 \pm 15.8 \mathrm{~m})$ shows the 

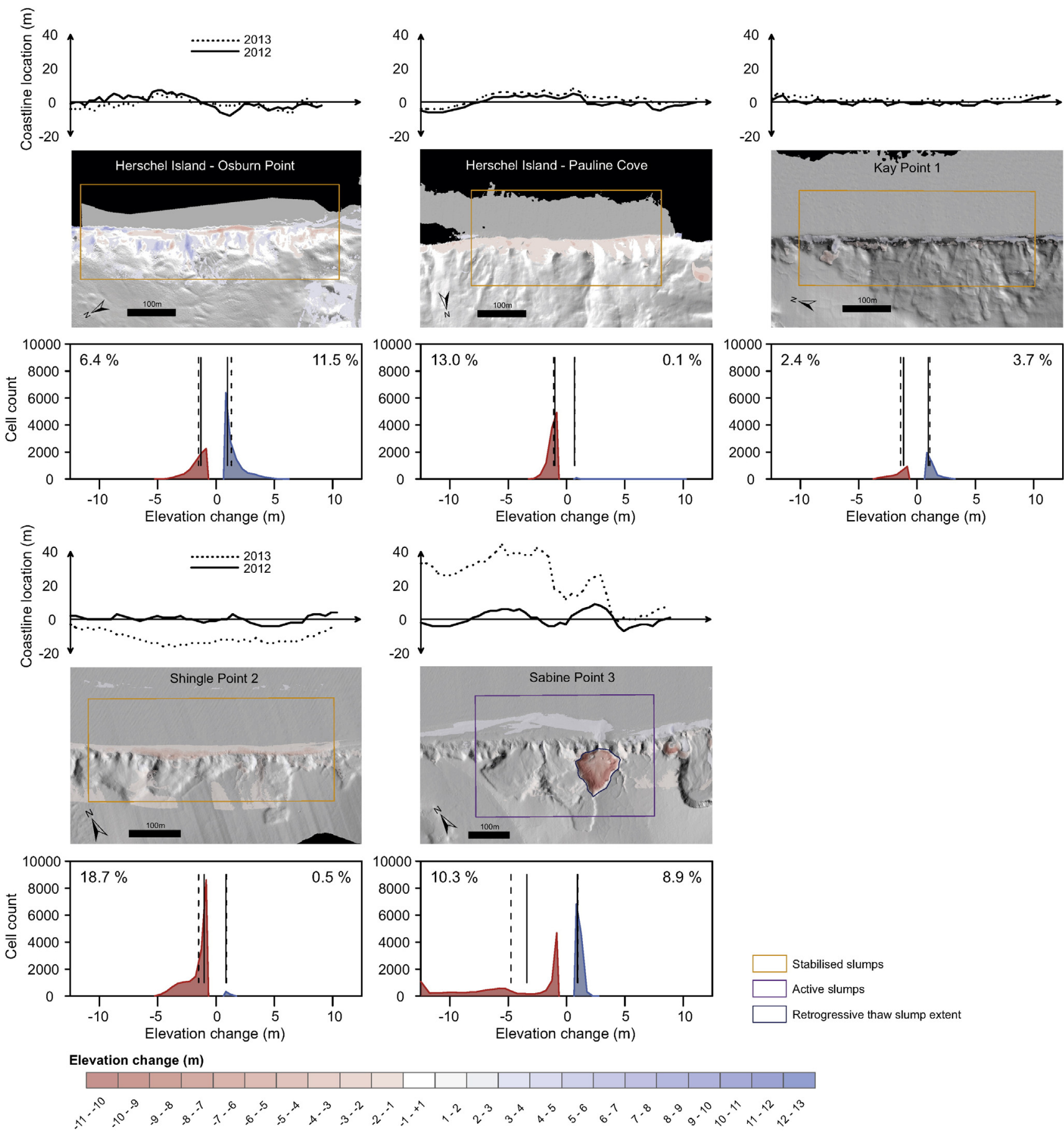

Fig. 8. Examples of study sites from stabilised and active slumps geomorphic units. RTS extents used for separate volume calculation are delineated with blue line.

uneven spatial distribution of geomorphic processes on the coast and in the backshore area.

Elevation decrease, volume change, and coastal retreat are variable within geomorphic units and across them (Tables 4 and 6 and Figs. 610). Regardless of geomorphic unit (except for beach-protected coast) sites underwent all; coastal erosion, inactivity or coastline progradation. The variability in the active-slumps unit can be explained by the different intensity of mass wasting processes. The highest elevation changes in this unit occurred at the site with an actively evolving RTS (Fig. 8, Sabine Point 3 ) and at the NE side of Herschel Island, which was the most exposed to waves and storm surges and consequent material removal (Fig. 6, Herschel Island - Bell Bluff 1). High variability within the lowbluffs unit occurred because it includes inactive bluffs and bluffs eroding by up to $20 \mathrm{~m}$ per year (Fig. 6, Stokes Point 2). This variability in sites unaffected by mass wasting is likely due to episodicity and high spatial and temporal variability of arctic coastal erosion (Are, 1988, Lantuit et al., 2012).

\subsection{Coastal erosion in different geomorphic units}

Coasts with low backshore elevations $(<10 \mathrm{~m})$ showed simple and uniform coastal retreat, while many coasts with high backshore elevations showed more diverse coastal dynamics. Mean coastline retreat was the highest and volume decrease was second-to-greatest within the low-bluff unit. High coastline retreat indicates that coastal erosion is efficient enough to remove all material transported to the coastline 

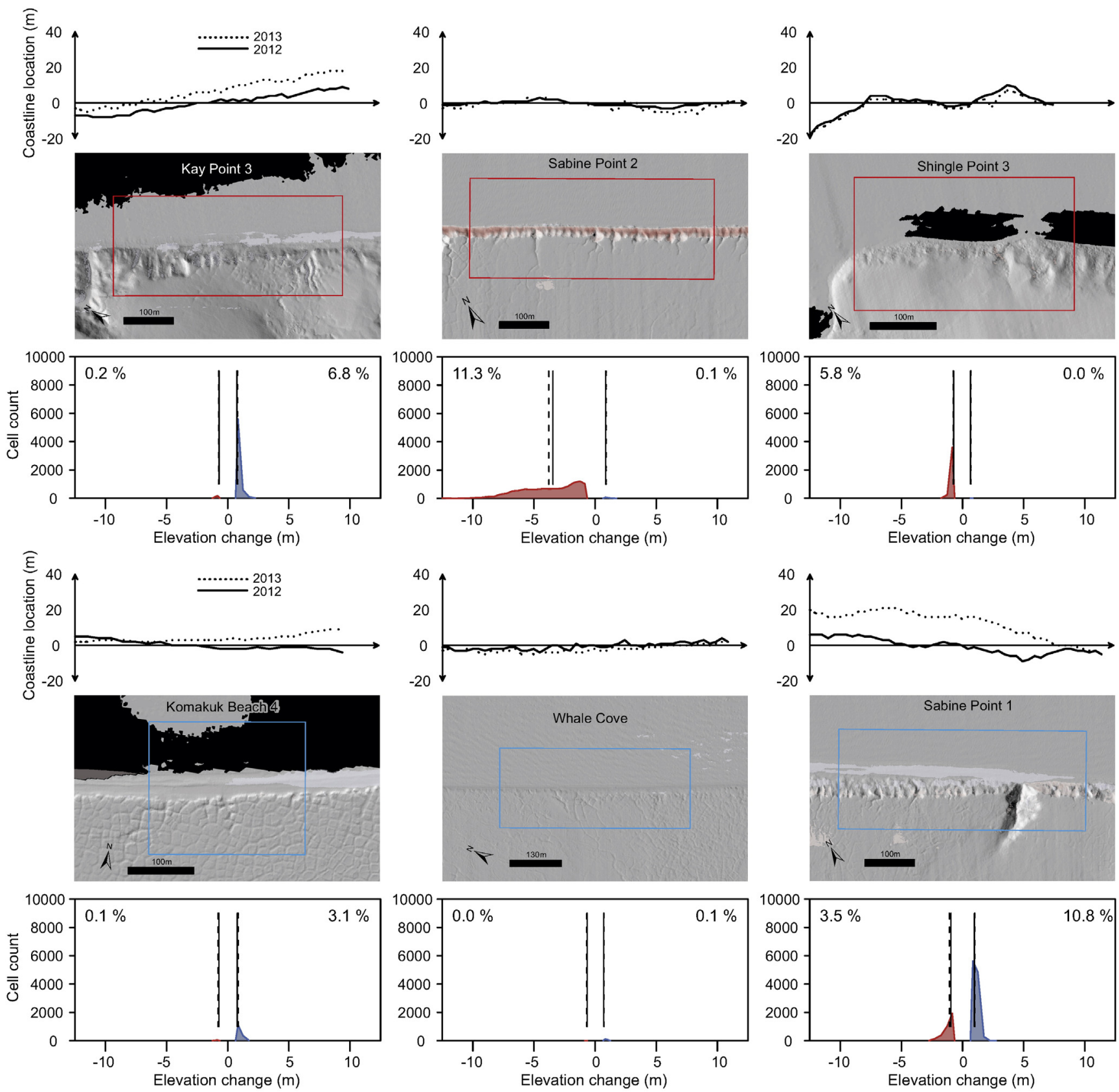

Elevation change $(\mathrm{m})$

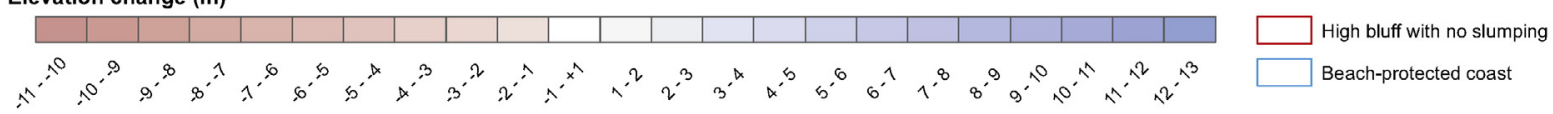

Fig. 9. Examples of study sites from high bluff units with no slumping and beach-protected coast geomorphic units.

by mass-wasting processes. To the contrary, mean coastline progradation on three active-slumps unit sites along the Yukon Coast, which have undergone the highest volume decrease, indicates that coastal erosion was not efficient enough to remove all of the material within the one year observation period. This suggests intermediate accumulation of eroded material after mobilisation, as shown by elevation increase in differenced DEMs. Sites from the same unit on the western and northern part of Herschel Island have conversely undergone considerable coastline retreat (on average 1.9-5.9 $\mathrm{m}$ at different sites) despite high volume decreases, because of more exposure to storm waves and surges. The stabilised slumps, where slumping was temporarily not active, showed the second highest coastal retreat and moderate volume loss.
The high bluffs with no slumping showed average erosional inactivity in the hinterland and average coastal progradation. However, all three high bluffs with no slumping sites showed different coastal dynamics. Shingle Point 3 was relatively stable, Kay Point 3 experienced beach accumulation, while Sabine Point 2 site showed volume loss on bluffs but no significant coastline retreat. This volume loss was of the same order as in the low-bluff unit at Stokes Point 2 site, which underwent up to $20 \mathrm{~m}$ of coastline retreat. This is indicating the importance of bluff height for coastal erosion although Héquette and Barnes (1990) indicated that erosion rates are insignificantly correlated to bluff height. The diversity of mass-wasting processes often present on bluffs higher than $10 \mathrm{~m}$ could be the reason for this insignificance. 

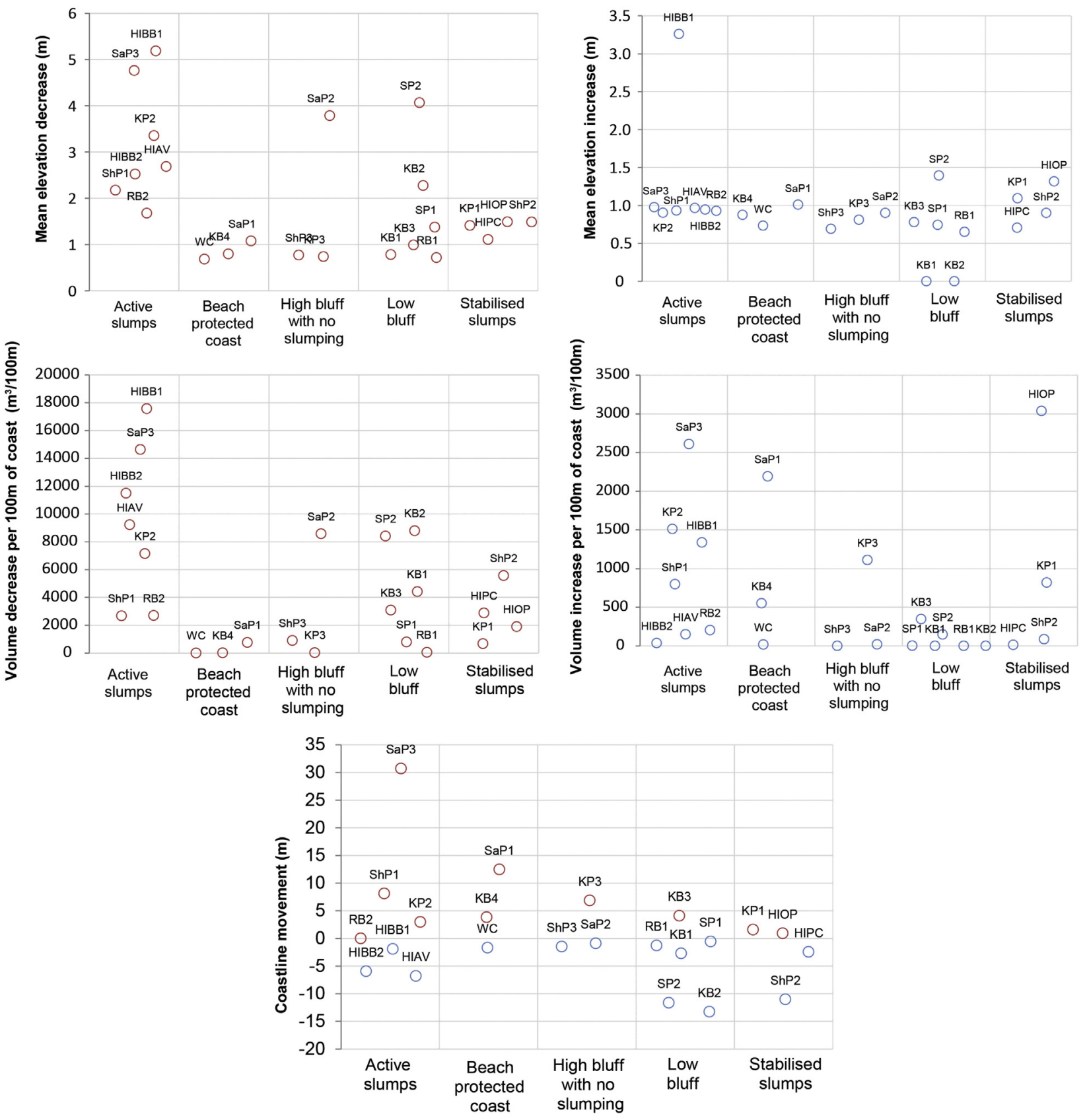

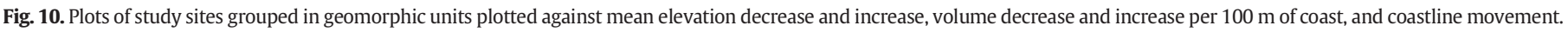
For coastline movement, retreat is shown as negative values.

The elevation decrease frequencies (Figs. 6-9) generally peaked towards $0 \mathrm{~m}$ in the most of the geomorphic units, which is because of slight subsidence recorded in the hinterland and beach erosion. Sites from the low bluff unit that underwent considerable coastal retreat (e.g. Komakuk Beach 2, Stokes point 2 and Sabine point 2) showed a bi-modal elevation decrease distribution with a second peak at the bluff height. Elevation change frequencies in the active slumps unit were very diverse (Fig. 11), which is indicating the variety of masswasting processes occurring along with coastal erosion.

\subsection{Factors influencing coastal erosion}

\subsubsection{Role of slumping}

Slumping can greatly impact patterns of erosion and deposition at a site or in the direction of longshore drift. Slumping was very common on the Yukon Coast and Herschel Island and occurred where the bluffs were higher than $10 \mathrm{~m}$. Sites with active slumping included most of the extreme values of erosion, accumulation, and coastline movements among the geomorphic units (Fig. 5). High average volume changes and coastline movements were also related to slumping events (Table 3 and Fig. 7). This indicates the importance of slumping, especially within RTSs, for altering the uniform coastal retreat. The effect of RTSs is evident at the Sabine Point 1 and 2 sites. The first site is located west of an active RTS and has experienced a strong sediment accumulation regime, whereas the second site, east of an RTS, has undergone strong erosion. The occurrence of slumping can hinder or temporarily stop coastal erosion on the coasts adjacent to RTSs because of the sediment supply to the shore.

Lantuit and Pollard (2008) and Leibman et al. (2008) suggested that RTS activity amplifies coastal erosion, because of massive ice presence and ground settlement. Our results show that short-term coastline retreat rates are lower in the units of active and stabilised 

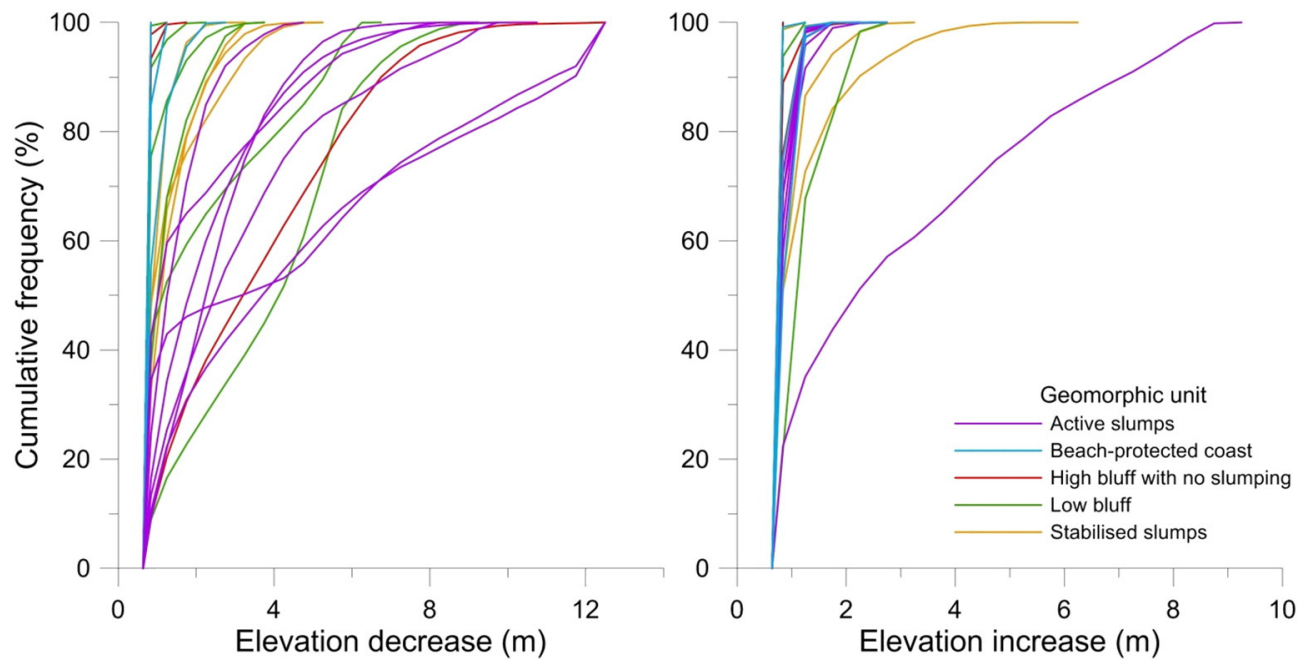

Fig. 11. Cumulative elevation decrease and increase frequencies for study sites grouped by geomorphic units.

slumps than in the low-bluff unit. The occurrences of RTSs can even result in short-term high coastline progradation rates, because of beach accumulation by sediment released from RTSs. However, this material, transported to the coastline by mass wasting, can again be removed within a few days during strong wave activity and within a few weeks during lower wave activity as observed by Leibman et al. (2008) on the Yugorsky Peninsula. Our LiDAR acquisitions, therefore, represent snapshots of the geomorphological state of the coast on the acquisition day, which could result in a recording of elevation increase and coastal progradation due to the presence of

Table 1

Classification of study sites according to prevailing geomorphic processes and morphology.

\begin{tabular}{|c|c|c|}
\hline $\begin{array}{l}\text { Geomorphic } \\
\text { unit }\end{array}$ & Description & Observed geomorphic processes \\
\hline Low bluff & coastal bluffs $<10 \mathrm{~m}$ height & coastal erosion and turf collapse \\
\hline Active slumps & coastal bluffs $>10 \mathrm{~m}$, evidence of active slumping & $\begin{array}{l}\text { coastal erosion, retrogressive thaw slumping, active-layer detachment sliding and large } \\
\text { material collapses }\end{array}$ \\
\hline Stabilised slumps & coastal bluffs $>10 \mathrm{~m}$, evidence of past slumping & coastal erosion and minor material collapses \\
\hline $\begin{array}{l}\text { High bluff with no } \\
\text { slumping }\end{array}$ & $\begin{array}{l}\text { coastal bluffs }>10 \mathrm{~m} \text {, no evidence of active or past } \\
\text { slumping }\end{array}$ & coastal erosion and minor material collapses \\
\hline Beach-protected coast & coast with well-expressed protecting beach & beach accumulation and lack of geomorphic processes in the hinterland \\
\hline
\end{tabular}

Table 2

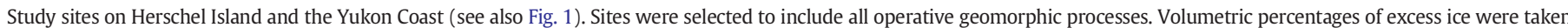
from Couture (2010), who averaged the percentage over terrain units along Yukon Coast and Herschel Island.

\begin{tabular}{|c|c|c|c|c|c|c|c|}
\hline Site name & Abbreviation & Geomorphic unit & $\begin{array}{l}\text { Maximal bluff height } \\
(\mathrm{m})\end{array}$ & $\begin{array}{l}\text { Section length } \\
(\mathrm{m})\end{array}$ & $\begin{array}{l}\text { Site area } \\
\left(\mathrm{m}^{2}\right)\end{array}$ & $\begin{array}{l}\text { Ice content } \\
(\%)\end{array}$ & $\begin{array}{l}\text { Excess ice content } \\
(\%)\end{array}$ \\
\hline Roland Bay 2 & RB2 & Active slumps & $12-20$ & 490 & 97,900 & 53.8 & 0.8 \\
\hline Kay Point 2 & KP2 & Active slumps & $10-20$ & 497 & 99,400 & 38.2 & 0.0 \\
\hline Shingle Point 1 & ShP1 & Active slumps & $15-30$ & 500 & 99,900 & 46.2 & 0.0 \\
\hline Sabine Point 3 & $\mathrm{SaP} 3$ & Active slumps & $20-30$ & 442 & 132,400 & 32.2 & 0.0 \\
\hline Herschel Island - Avadlek & HIAV & Active slumps & $10-25$ & 510 & 102,000 & 51.3 & 4.5 \\
\hline Herschel Island - Bell Bluff 1 & HIBB1 & Active slumps & 35 & 288 & 57,600 & 50.2 & 2.2 \\
\hline Herschel Island - Bell Bluff 2 & HIBB2 & Active slumps & $30-35$ & 668 & 133,600 & 50.2 & 2.2 \\
\hline Komakuk Beach 4 & KB4 & Beach-protected coasts & 5 & 236 & 47,100 & 57.7 & 22.2 \\
\hline Whale Cove & WC & Beach-protected coasts & $1-2$ & 478 & 95,700 & 57.3 & 16.7 \\
\hline Sabine Point 1 & SaP1 & Beach-protected coasts & $20-22$ & 497 & 99,400 & 30.4 & 0.0 \\
\hline Kay Point 3 & KP3 & High bluff with no slumping & $12-30$ & 460 & 91,900 & 38.2 & 0.0 \\
\hline Sabine Point 2 & $\mathrm{SaP2}$ & High bluff with no slumping & 21 & 490 & 98,100 & 59.7 & 20.1 \\
\hline Shingle Point 3 & ShP3 & High bluff with no slumping & $10-20$ & 331 & 66,100 & 40.4 & 0.0 \\
\hline Komakuk Beach 2 & KB2 & Low bluff & 6 & 394 & 78,800 & 52.3 & 11.8 \\
\hline Komakuk Beach 1 & KB1 & Low bluff & 3 & 334 & 66,700 & 52.3 & 11.8 \\
\hline Komakuk Beach 3 & KB3 & Low bluff & 7 & 379 & 75,900 & 57.7 & 22.2 \\
\hline Stokes Point 2 & SP2 & Low bluff & $4-15$ & 456 & 91,200 & 53.2 & 0.0 \\
\hline Roland Bay 1 & RB1 & Low bluff & $2-5$ & 461 & 92,300 & 51.5 & 0.0 \\
\hline Stokes Point 1 & SP1 & Low bluff & 9 & 365 & 73,100 & 53.2 & 0.0 \\
\hline Kay Point 1 & KP1 & Stabilised slumps & $20-30$ & 497 & 99,400 & 38.2 & 0.0 \\
\hline Shingle Point 2 & ShP2 & Stabilised slumps & $20-27$ & 477 & 95,500 & 46.2 & 0.0 \\
\hline Herschel Island - Osburn Point & HIOP & Stabilised slumps & $20-30$ & 545 & 109,000 & 55.5 & 13.0 \\
\hline Herschel Island - Pauline Cove & HIPC & Stabilised slumps & $15-20$ & 397 & 79,500 & 55.5 & 13.0 \\
\hline
\end{tabular}


Table 3

Elevation change at the study sites. Statistics for elevation decrease and elevation increase were calculated separately. Observation period is from 10 July $2012-22$ July 2013.

\begin{tabular}{|c|c|c|c|c|c|c|c|c|c|}
\hline \multicolumn{10}{|l|}{ Elevation decrease } \\
\hline Unit & \multicolumn{2}{|l|}{ Geomorphic unit } & \multicolumn{2}{|c|}{$\begin{array}{l}\text { Area that underwent the change } \\
(\%)\end{array}$} & \multirow{2}{*}{$\begin{array}{l}\begin{array}{l}\text { Mean } \\
(\mathrm{m})\end{array} \\
1.7\end{array}$} & $\begin{array}{l}\text { Median } \\
(\mathrm{m})\end{array}$ & $\begin{array}{l}\text { STD } \\
(\mathrm{m})\end{array}$ & $\begin{array}{l}\text { Maximum } \\
(\mathrm{m})\end{array}$ & $\begin{array}{l}\text { Volume decrease per } 100 \mathrm{~m} \text { of coastline } \\
\left(\mathrm{m}^{3} / 100 \mathrm{~m}\right)\end{array}$ \\
\hline Roland Bay 2 & Active slumps & & 8.0 & & & 1.5 & 0.8 & 5.0 & 2699 \\
\hline Kay Point 2 & Active slumps & & 10.7 & & 3.4 & 2.7 & 2.3 & 9.9 & 7152 \\
\hline Shingle Point 1 & Active slumps & & 6.2 & & 2.2 & 1.2 & 1.9 & 8.4 & 2679 \\
\hline Sabine Point 3 & Active slumps & & 10.3 & & 4.8 & 3.4 & 4.4 & 18.9 & 14,639 \\
\hline HI - Avadlek & Active slumps & & 17.2 & & 2.7 & 2.5 & 1.4 & 9.3 & 9226 \\
\hline HI - Bell Bluff 1 & Active slumps & & 16.9 & & 5.2 & 3.9 & 4.1 & 17.0 & 17,573 \\
\hline HI - Bell Bluff 2 & Active slumps & & 22.8 & & 2.5 & 2.1 & 1.7 & 10.8 & 11,497 \\
\hline Komakuk Beach 4 & Beach-protected coas & & 0.1 & & 0.8 & 0.7 & 0.2 & 1.3 & 18 \\
\hline Whale Cove & Beach-protected coas & & 0.0 & & 0.7 & 0.7 & 0.0 & 0.8 & 1 \\
\hline Sabine Point 1 & Beach-protected coas & & 3.5 & & 1.1 & 1.0 & 0.4 & 2.8 & 760 \\
\hline Kay Point 3 & High bluff with no slu & mping & 0.2 & & 0.7 & 0.7 & 0.1 & 1.1 & 29 \\
\hline Sabine Point 2 & High bluff with no slu & mping & 11.3 & & 3.8 & 3.5 & 2.3 & 13.6 & 8576 \\
\hline Shingle Point 3 & High bluff with no slu & mping & 5.8 & & 0.8 & 0.7 & 0.1 & 1.9 & 901 \\
\hline Komakuk Beach 2 & Low bluff & & 19.3 & & 2.3 & 1.4 & 1.9 & 6.5 & 8803 \\
\hline Komakuk Beach 1 & Low bluff & & 28.3 & & 0.8 & 0.7 & 0.2 & 2.4 & 4417 \\
\hline Komakuk Beach 3 & Low bluff & & 15.6 & & 1.0 & 0.8 & 0.5 & 3.9 & 3087 \\
\hline Stokes Point 2 & Low bluff & & 10.3 & & 4.1 & 4.4 & 2.1 & 9.7 & 8416 \\
\hline Roland Bay 1 & Low bluff & & 0.4 & & 0.7 & 0.7 & 0.1 & 1.1 & 52 \\
\hline Stokes Point 1 & Low bluff & & 2.9 & & 1.4 & 1.2 & 0.7 & 3.8 & 802 \\
\hline Kay Point 1 & Stabilised slumps & & 2.4 & & 1.4 & 1.2 & 0.7 & 3.7 & 680 \\
\hline Shingle Point 2 & Stabilised slumps & & 18.7 & & 1.5 & 1.0 & 1.0 & 5.4 & 5569 \\
\hline HI - Osburn Point & Stabilised slumps & & 6.4 & & 1.5 & 1.3 & 0.7 & 5.1 & 1897 \\
\hline $\mathrm{HI}$ - Pauline Cove & Stabilised slumps & & 13.0 & & 1.1 & 1.0 & 0.4 & 3.2 & 2885 \\
\hline \multicolumn{10}{|l|}{ Elevation increase } \\
\hline Unit & Geomorphic unit & $\begin{array}{l}\text { Area th } \\
(\%)\end{array}$ & lat underwent the change & $\begin{array}{l}\text { Mean } \\
(\mathrm{m})\end{array}$ & $\begin{array}{l}\text { Median } \\
(\mathrm{m})\end{array}$ & $\begin{array}{l}\text { STD } \\
(\mathrm{m})\end{array}$ & $\begin{array}{l}\text { Max } \\
(\mathrm{m})\end{array}$ & num & $\begin{array}{l}\text { ume increase per } 100 \mathrm{~m} \text { of coastline } \\
/ 100 \mathrm{~m})\end{array}$ \\
\hline Roland Bay 2 & Active slumps & 1.1 & & 0.9 & 0.8 & 0.3 & 2.0 & 2 & \\
\hline Kay Point 2 & Active slumps & 8.4 & & 0.9 & 0.8 & 0.2 & 2.1 & 15 & \\
\hline Shingle Point 1 & Active slumps & 4.3 & & 0.9 & 0.9 & 0.3 & 2.7 & 7 & \\
\hline Sabine Point 3 & Active slumps & 8.9 & & 1.0 & 0.9 & 0.3 & 2.7 & 26 & \\
\hline HI - Avadlek & Active slumps & 0.8 & & 1.0 & 0.9 & 0.3 & 2.7 & 1 & \\
\hline HI - Bell Bluff 1 & Active slumps & 2.1 & & 3.3 & 2.4 & 2.5 & 9.0 & 13 & \\
\hline HI - Bell Bluff 2 & Active slumps & 0.2 & & 0.9 & 0.9 & 0.2 & 1.6 & & 6 \\
\hline \multicolumn{10}{|l|}{ Komakuk Beach } \\
\hline 4 & Beach-protected coasts & 3.1 & & 0.9 & 0.8 & 0.2 & 1.6 & 5 & \\
\hline Whale Cove & Beach-protected coasts & 0.1 & & 0.7 & 0.7 & 0.1 & 1.0 & & 8 \\
\hline Sabine Point 1 & $\begin{array}{l}\text { Beach-protected coasts } \\
\text { High bluff with no }\end{array}$ & 10.8 & & 1.0 & 1.0 & 0.2 & 2.6 & 21 & \\
\hline Kay Point 3 & $\begin{array}{l}\text { slumping } \\
\text { High bluff with no }\end{array}$ & 6.8 & & 0.8 & 0.8 & 0.2 & 2.5 & 11 & \\
\hline Sabine Point 2 & $\begin{array}{l}\text { slumping } \\
\text { High bluff with no }\end{array}$ & 0.1 & & 0.9 & 0.9 & 0.2 & 1.6 & & 0 \\
\hline $\begin{array}{l}\text { Shingle Point } 3 \\
\text { Komakuk Beach }\end{array}$ & slumping & 0.0 & & \multicolumn{5}{|c|}{ Komakuk Beach } & 1 \\
\hline 2 & Low bluff & 0.0 & & 0.0 & 0.0 & 0.0 & 0.0 & & 0 \\
\hline \multicolumn{10}{|l|}{ Komakuk Beach } \\
\hline 1 & Low bluff & 0.0 & & 0.0 & 0.0 & 0.0 & 0.0 & & 0 \\
\hline \multicolumn{10}{|l|}{ Komakuk Beach } \\
\hline 3 & Low bluff & 2.2 & & 0.8 & 0.8 & 0.1 & 1.0 & 3 & \\
\hline Stokes Point 2 & Low bluff & 0.5 & & 1.4 & 1.2 & 0.5 & 2.7 & 1 & \\
\hline Roland Bay 1 & Low bluff & 0.0 & & 0.7 & 0.7 & 0.0 & 0.7 & & 0 \\
\hline Stokes Point 1 & Low bluff & 0.0 & & 0.7 & 0.7 & 0.1 & 1.0 & & 3 \\
\hline Kay Point 1 & Stabilised slumps & 3.7 & & 1.1 & 1.0 & 0.4 & 3.3 & 8 & \\
\hline $\begin{array}{l}\text { Shingle Point } 2 \\
\text { HI - Osburn }\end{array}$ & Stabilised slumps & 0.5 & & 0.9 & 0.8 & 0.2 & 1.7 & & 7 \\
\hline $\begin{array}{l}\text { Point } \\
\text { HI - Pauline }\end{array}$ & Stabilised slumps & 11.5 & & 1.3 & 1.0 & 0.8 & 6.1 & 30 & \\
\hline Cove & Stabilised slumps & 0.1 & & 0.7 & 0.7 & 0.1 & 1.0 & & 4 \\
\hline
\end{tabular}

short-lived mass wasting depositional features. High progradation rates were also observed because of material accumulated from rapid slope collapse (Bell Bluff 1 site), where the material persisted for a longer time because it was less reworked.

Small thermo-erosional niches were observed in bluffs with low backshore elevations, which are more similar to parts of the Beaufort Sea where they were observed by Kobayashi (1985) and Barnhart et al. (2014a). Thermo-erosional niches and related block failures were absent in bluffs with high backshore elevations, presumably because of very active slumping, which is transporting material to the shore.

Volume increase that was recorded inside RTS areas (limited to RTS extent inside study sites shown in Figs. 7 and 8) over the study period accounted for $5.5 \%$ of the volume decrease, meaning that at least $5.5 \%$ of the material that has been activated is temporarily stored inside RTSs and not directly transported to the sea. The excess ice percentage at our slump sites was zero or negligible (Couture, 2010), so the same 
Table 4

Elevation change at the study sites grouped by geomorphic unit.

\begin{tabular}{|c|c|c|c|c|c|c|}
\hline \multicolumn{7}{|l|}{ Elevation decrease } \\
\hline Unit & Number of sections & Mean (m) & Median (m) & $\mathrm{STD}(\mathrm{m})$ & Maximum (m) & $\begin{array}{l}\text { Volume decrease per } 100 \mathrm{~m} \\
\text { of coastline }\left(\mathrm{m}^{3} / 100 \mathrm{~m}\right)\end{array}$ \\
\hline Low bluff & 6 & 1.8 & 0.8 & 1.8 & 9.6 & 4235 \\
\hline High bluff with no slumping & 3 & 3.0 & 2.1 & 2.4 & 13.4 & 3519 \\
\hline Beach-protected coasts & 3 & 1.1 & 0.9 & 0.4 & 2.6 & 310 \\
\hline Active slumps & 7 & 3.1 & 2.2 & 2.8 & 18.6 & 8833 \\
\hline Stabilised slumps & 4 & 1.4 & 1.1 & 0.8 & 5.3 & 2686 \\
\hline All sites & 23 & 2.4 & 1.5 & 2.4 & 18.6 & 4918 \\
\hline \multicolumn{7}{|l|}{ Elevation increase } \\
\hline Unit & Number of sections & Mean $(\mathrm{m})$ & Median (m) & $\mathrm{STD}(\mathrm{m})$ & Maximum (m) & $\begin{array}{l}\text { Volume increase per } 100 \mathrm{~m} \\
\text { of coastline }\left(\mathrm{m}^{3} / 100 \mathrm{~m}\right)\end{array}$ \\
\hline Low bluff & 6 & 0.9 & 0.8 & 0.4 & 2.6 & 83 \\
\hline High bluff with no slumping & 3 & 0.8 & 0.8 & 0.2 & 2.3 & 401 \\
\hline Beach-protected coasts & 3 & 1.0 & 1.0 & 0.2 & 2.4 & 1012 \\
\hline Active slumps & 7 & 1.0 & 0.9 & 0.7 & 9.1 & 840 \\
\hline Stabilised slumps & 4 & 1.3 & 1.0 & 0.8 & 5.7 & 1074 \\
\hline All sites & 23 & 1.1 & 0.9 & 0.6 & 9.1 & 672 \\
\hline
\end{tabular}

volume which has been eroded can potentially be accumulated. Activated material can be slowly moved towards the RTS outlet without observed volume increases. For this reason the percentage of temporarily accumulated sediment can be higher than we recorded. The fraction that stayed within the slump during one year is relevant for the quantification of carbon output from RTSs, because material that is not directly transported to the sea is exposed to aerobic processes and therefore increased microbial activity (Pautler et al., 2010). This can decrease the amount of stored carbon and increase direct $\mathrm{CO}_{2}$ emissions from RTSs to the atmosphere (Vonk et al., 2012).

\subsubsection{Role of beaches and accumulation}

Coasts protected by beaches show relative stability or even accumulation. This unit has undergone the lowest erosion, but significant material accumulation and coastline progradation of up to $20 \mathrm{~m}$ occurred (Tables 3, 4 and Fig. 9). The volume decrease made up only $8 \%$ of the volume increase in this unit, meaning that accumulated material doesn't originate from hinterland but is transported by longshore drift from elsewhere. Rampton (1982) associated beaches with coarse-grain sediments, because silty sediment is easily suspended in the water, transported offshore, and therefore unlikely to accumulate on the beach (Are, 1988). To relate occurrence of beaches to grain size in our study area, detailed mapping of sediments would be required. Sediment transported by longshore drift can originate from mass wasting, coastal erosion, or distributary streams. Lantuit and Pollard (2008) reported that bluffs on SE Herschel Island are affected by beach armouring because of distributary streams. When the sediment supply ceases, the accumulated beach can undergo high coastline retreat rates, since unconsolidated beach sediment can be rapidly eroded (e. g. Shingle Point 2 site).

\subsection{Suitability of the airborne LiDAR dataset for coastal erosion studies}

Airborne LiDAR datasets provide highly accurate information about coastline variations along rapidly evolving ice-rich Arctic coasts. The coastline has often been defined as the land-ocean interface (Solomon,

Table 5

Coastline movements and hinterland erosion lengths for study sites. Statistics was calculated based on transects with $10 \mathrm{~m}$ spacing in the study sites.

\begin{tabular}{|c|c|c|c|c|c|c|c|c|}
\hline \multirow[b]{2}{*}{ Site } & \multirow[b]{2}{*}{ Geomorphic unit } & \multicolumn{4}{|c|}{ Coastline movement (m) } & \multicolumn{3}{|c|}{ Hinterland erosion length (m) } \\
\hline & & Mean & STD & Max. retreat & Max. progradation & Mean & STD & Max \\
\hline Roland Bay 2 & Active slumps & 0.0 & 1.5 & -3 & 4 & 14.5 & 8.4 & 34 \\
\hline Kay Point 2 & Active slumps & 3.0 & 2.1 & -1 & 8 & 20.1 & 17.7 & 65 \\
\hline Shingle Point 1 & Active slumps & 8.1 & 3.9 & -1 & 14 & 9.8 & 12.9 & 50 \\
\hline Sabine Point 3 & Active slumps & 30.7 & 8.1 & 0 & 42 & 13.3 & 25.3 & 113 \\
\hline HI - Avadlek & Active slumps & -6.8 & 8.6 & -22 & 6 & 32.2 & 9.4 & 59 \\
\hline HI - Bell Bluff 1 & Active slumps & -1.9 & 8.4 & -10 & 22 & 28.7 & 8.9 & 51 \\
\hline HI - Bell Bluff 2 & Active slumps & -5.9 & 3.4 & -17 & 1 & 31.8 & 13.5 & 65 \\
\hline Komakuk Beach 4 & Beach-protected coasts & 3.8 & 4.2 & -3 & 13 & 0.3 & 1.0 & 5 \\
\hline Whale Cove & Beach-protected coasts & -1.7 & 1.2 & -5 & 0 & 0.0 & 0.1 & 1 \\
\hline Sabine Point 1 & Beach-protected coasts & 12.5 & 5.7 & 0 & 20 & 5.2 & 6.0 & 25 \\
\hline Kay Point 3 & High bluff with no slumping & 6.9 & 2.3 & 2 & 11 & 0.3 & 0.6 & 2 \\
\hline Sabine Point 2 & High bluff with no slumping & -0.9 & 1.5 & -5 & 2 & 21.9 & 3.9 & 30 \\
\hline Shingle Point 3 & High bluff with no slumping & -1.5 & 1.3 & -7 & 0 & 5.3 & 4.6 & 18 \\
\hline Komakuk Beach 2 & Low bluff & -13.3 & 2.3 & -18 & -8 & 26.1 & 3.5 & 33 \\
\hline Komakuk Beach 1 & Low bluff & -2.7 & 1.9 & -6 & 1 & 36.7 & 15.6 & 68 \\
\hline Komakuk Beach 3 & Low bluff & 4.1 & 4.1 & -4 & 10 & 16.7 & 9.2 & 37 \\
\hline Stokes Point 2 & Low bluff & -11.6 & 4.3 & -21 & -6 & 20.3 & 4.3 & 30 \\
\hline Roland Bay 1 & Low bluff & -1.3 & 1.8 & -5 & 2 & 0.5 & 1.0 & 3 \\
\hline Stokes Point 1 & Low bluff & -0.6 & 1.0 & -2 & 1 & 5.5 & 3.2 & 12 \\
\hline Kay Point 1 & Stabilised slumps & 1.6 & 1.4 & -1 & 4 & 4.1 & 5.9 & 30 \\
\hline Shingle Point 2 & Stabilised slumps & -11.0 & 3.3 & -17 & -5 & 23.8 & 7.1 & 39 \\
\hline HI - Osburn Point & Stabilised slumps & 0.9 & 3.0 & -6 & 8 & 10.2 & 7.7 & 38 \\
\hline HI - Pauline Cove & Stabilised slumps & -2.4 & 0.9 & -4 & -1 & 19.9 & 8.8 & 48 \\
\hline
\end{tabular}


Coastline movements and hinterland erosion lengths for study sites grouped by geomorphic unit type.

\begin{tabular}{|c|c|c|c|c|c|c|c|c|c|c|}
\hline \multirow[b]{2}{*}{ Unit } & \multirow[b]{2}{*}{ Number of transects } & \multicolumn{5}{|c|}{ Coastline movement (m) } & \multicolumn{4}{|c|}{ Hinterland erosion length (m) } \\
\hline & & Mean & Median & STD & Max. retreat & Max. progradation & Mean & Median & STD & Max \\
\hline Low bluff & 236 & -4.5 & -3 & 6.9 & -21 & 10 & 16.9 & 17 & 14.0 & 68 \\
\hline High bluff with no slumping & 128 & 1.7 & 0 & 4.3 & -7 & 11 & 9.8 & 5 & 10.3 & 30 \\
\hline Beach-protected coasts & 120 & 5.2 & 2 & 7.6 & -5 & 20 & 2.2 & 0 & 4.6 & 25 \\
\hline Active slumps & 337 & 2.2 & 0 & 11.4 & -22 & 42 & 23.3 & 23 & 19.0 & 113 \\
\hline Stabilised slumps & 188 & -2.6 & -1 & 5.6 & -17 & 8 & 14.0 & 14 & 10.7 & 48 \\
\hline All sites & 1009 & 0.1 & 0 & 9.0 & -22 & 42 & 15.8 & 14 & 15.8 & 113 \\
\hline
\end{tabular}

2005; Lantuit and Pollard, 2008; Jones et al., 2009). According to this definition, the coastline also includes beaches, which in our study showed considerable variations in the vicinity of RTSs (up to $40 \mathrm{~m}$ of prograded coast). The collapsed material and material that was moved by mass wasting sometimes resulted in progradation of the coastline to a distance of up to $20 \mathrm{~m}$. These occasional events can significantly affect the coastline digitalisations and can present a source of variations in the estimations of retreat rates. Thus the digitalisation of cliff bottom line (as done by Günther et al., 2013) might be more suitable for the estimation of coastal retreat rates in permafrost regions.

Use of airborne LiDAR datasets is limited in the case of overhangs, because the volume underneath cannot be recorded. These overhangs were present in some low-bluff coastal study sites (e.g. Stokes Point 2 ), but did not exceed $1 \mathrm{~m}$ in width. Assuming that overhangs are continuously developing, the volume calculation uncertainty originating from their presence in our datasets can be neglected because it is similar in both datasets.

We discussed the influence of mass-wasting processes on permafrost coastal erosion. A possible perspective on detecting short-term and inter-annual changes is to relate observed changes also to other local and regional factors. This can improve our understanding of processes, modelling accuracies, and subsequent prediction of the future development of Arctic coastal erosion under increasing air temperatures and lengthening open-water season duration (Barnhart et al., 2014b). The major advantage of repeat airborne LiDAR elevation data compared to stereophotogrammetry is the unique high accuracy and the possibility of multiple short observation periods.

\section{Conclusion}

Our study indicates considerable spatial variability in short-term coastline erosion and progradation, which cannot be resolved by longterm observation. This variability is significantly related to a wide spectrum of mass-wasting processes acting on permafrost coasts. Comparison between geomorphic units revealed that erosion behaviour is simple and relatively uniform at low-elevation coasts and becomes diverse at higher-elevation coasts, where mass-wasting processes are more active. Among these processes, retrogressive thaw slumping is particularly important. RTS occurrence affects not only the coastal processes at slump outlet, but also nearby coasts with sediment input and accumulation. Most of the erosion and deposition extremes were recorded at sites with slumping activity. On average at least 5.5\% of the eroded material was temporarily accumulated again inside RTSs, meaning that material was exposed to aerobic conditions which could activate stored organic carbon before material is transported to the sea. Our study also showed that short-term coastline movements, such as beach progradation or block failures, can be intensive but, as indicated by other studies, can be generally short-lived features along permafrost coasts. These variations must be considered when digitising coastlines from air photos or satellite imagery as a land-ocean interface. Our short-term study demonstrated the effect of mass wasting on coastal dynamics and can serve as a baseline for coastal erosion modelling.
Further short-term studies can reveal the exact relationships between other factors controlling erosion along permafrost coasts.

\section{Acknowledgements}

Authors would like to kindly thank Katy Barnhart and anonymous reviewer for their constructive comments. The study was financially supported by the Helmholtz Association through the COPER young researchers group (grant VH-NG-801) and by the Alfred Wegener Institute Potsdam. Jaroslav Obu was financially supported by the Slovene Human Resources Development and Scholarship Fund. Torsten Sachs was supported by the Helmholtz Association of German Research Centres through a Helmholtz Young Investigators Group (grant VH-NG821), and GG was supported by ERC 338335.

\section{References}

Are, F.E., 1988. Thermal abrasion of sea coasts. Polar Geogr. Geol 12, 2

Atkinson, D.E., 2005. Observed storminess patterns and trends in the circum-Arctic coastal regime. Geo-Marine Letters 25, 98-109.

Barnhart, K.R., Anderson, R.S., Overeem, I., Wobus, C., Clow, G.D., Urban, F.E., 2014a. Modeling erosion of ice-rich permafrost bluffs along the Alaskan Beaufort Sea coast. J. Geophys. Res. Earth Surf. 119, 1155-1179. http://dx.doi.org/10.1002/ 2013JF002845.

Barnhart, K.R., Overeem, I., Anderson, R.S., 2014b. The effect of changing sea ice on the physical vulnerability of Arctic coasts. Cryosphere 8, 1777-1799. http://dx.doi.org/ 10.5194/tc-8-1777-2014.

Bird, E., 2011. Coastal Geomorphology: An Introduction. John Wiley \& Sons.

Bouchard, M., 1974. Géologie des dépôts meubles de l'île Herschel, territoire du Yukon (MSc Thesis) Université de Montréal, Montréal.

Burn, C.R., Lewkowicz, A.G., 1990. Canadian landform examples-17 retrogressive thaw slumps. Can. Geogr. Géogr. Can. 34, 273-276.

Canadian Hydrographic Service, 2015. Tides, currents, and Water levels [WWW Document]. URL. http://www.tides.gc.ca/eng (accessed 1.8.16).

Couture, N.J., 2010. Fluxes of soil organic carbon from eroding permafrost coasts, Canadian Beaufort Sea (PhD Thesis) University of Montreal, Montreal.

Dallimore, S.R., Wolfe, S.A., Solomon, S.M., 1996. Influence of ground ice and permafrost on coastal evolution, Richards Island, Beaufort Sea coast, NWT. Can. J. Earth Sci. 33, 664-675.

Environment Canada, 2015. Historical Climate data [WWW Document]. http://climate. weather.gc.ca (accessed 3.6.15).

Fritz, M., Wetterich, S., Schirrmeister, L., Meyer, H., Lantuit, H., Preusser, F., Pollard, W.H., 2012. Eastern Beringia and beyond: late Wisconsinan and Holocene landscape dynamics along the Yukon Coastal Plain. Canada. Palaeogeogr. Palaeoclimatol. Palaeoecol. 319, 28-45.

Günther, F., Overduin, P.P., Sandakov, A., Grosse, G., Grigoriev, M.N., 2012. Thermoerosion along the Yedoma Coast of the Buor Khaya Peninsula, Laptev Sea, East Siberia. Proceedings of the Tenth International Conference on Permafrost, Volume 1: International Contributions. The Northern Publisher, Salekhard, Russia, pp. 137-142.

Günther, F., Overduin, P.P., Sandakov, A.V., Grosse, G., Grigoriev, M.N., 2013. Short- and long-term thermo-erosion of ice-rich permafrost coasts in the Laptev Sea region. Biogeosciences 10, 4297-4318. http://dx.doi.org/10.5194/bg-10-4297-2013.

Günther, F., Overduin, P.P., Yakshina, I.A., Opel, T., Baranskaya, A.V., Grigoriev, M.N., 2015. Observing Muostakh disappear: permafrost thaw subsidence and erosion of a ground-ice-rich island in response to arctic summer warming and sea ice reduction. Cryosphere 9, 151-178. http://dx.doi.org/10.5194/tc-9-151-2015.

Héquette, A., Barnes, P.W., 1990. Coastal retreat and shoreface profile variations in the Canadian Beaufort Sea. Mar. Geol. 91, 113-132.

Hoque, M.A., Pollard, W.H., 2009. Arctic coastal retreat through block failure. Can. Geotech. J. 46, 1103-1115.

Hudak, D.R., Young, J.M.C., 2002. Storm climatology of the southern Beaufort Sea. Atmosphere-Ocean 40, 145-158. 
Hughes, O.L., 1972. Surficial Geology of Northern Yukon Territory and Northwestern District of Mackenzie, Northwest Territories. Department of Energy, Mines and Resources.

Hynes, S., Solomon, S.M., Forbes, D.L., Whalen, D., Manson, G.L., 2014. GIS compilation of coastline variability spanning 60 years, western Beaufort Sea, Yukon and Northwest Territories. Geol. Surv. Can. http://dx.doi.org/10.4095/293926.

Jaw, J.A.W., 2001. Statistics-based Fusion of Terrain Data Sets and Change Detection. 22nd Asian Conference on Remote Sensing. Presented at the 22nd Asian Conference on Remote Sensing, Singapore, p. 9.

Jones, B.M., Arp, C.D., Jorgenson, M.T., Hinkel, K.M., Schmutz, J.A., Flint, P.L., 2009. Increase in the rate and uniformity of coastline erosion in Arctic Alaska. Geophys. Res. Lett. 36, L03503. http://dx.doi.org/10.1029/2008GL036205.

Jones, B.M., Stoker, J.M., Gibbs, A.E., Grosse, G., Romanovsky, V.E., Douglas, T.A., Kinsman, N.E.M., Richmond, B.M., 2013. Quantifying landscape change in an arctic coastal lowland using repeat airborne LiDAR. Environ. Res. Lett. 8, 045025. http://dx.doi.org/10. 1088/1748-9326/8/4/045025.

Kobayashi, N., 1985. Formation of thermoerosional niches into frozen bluffs due to storm surges on the Beaufort Sea coast. J. Geophys. Res. 90, 11983-11988. http://dx.doi.org/ 10.1029/JC090iC06p11983.

Kohnert, K., Serafimovich, A., Hartmann, J., Sachs, T., 2014. Airborne measurements of methane fluxes in Alaskan and Canadian tundra with the research aircraft Polar 5. Berichte zur Polar-und Meeresforschung $=$ Reports on polar and marine research 673.

Lantuit, H., Pollard, W.H., 2005. Temporal stereophotogrammetric analysis of retrogressive thaw slumps on Herschel Island, Yukon Territory. Nat. Hazards Earth Syst. Sci. $5,413-423$.

Lantuit, H., Pollard, W.H., 2008. Fifty years of coastal erosion and retrogressive thaw slump activity on Herschel Island, southern Beaufort Sea, Yukon Territory, Canada. Geomorphology 95, 84-102.

Lantuit, H., Overduin, P.P., Couture, N., Wetterich, S., Aré, F., Atkinson, D., Brown, J., Cherkashov, G., Drozdov, D., Forbes, D.L., 2012. The Arctic coastal dynamics database: a new classification scheme and statistics on Arctic permafrost coastlines. Estuar. Coasts 35, 383-400.

Lantz, T.C., Kokelj, S.V., 2008. Increasing rates of retrogressive thaw slump activity in the Mackenzie Delta region, N.W.T., Canada. Geophys. Res. Lett. 35, L06502. http://dx.doi. org/10.1029/2007GL032433.

Leibman, M., Gubarkov, A., Khomutov, A., Kizyaakov, A., Vanshtein, B., 2008. Coastal Processes at the Tabular-Ground-Ice-Bearing Area, Yugorsky Peninsula, Russia. Proceedings of the 9th International Conference on Permafrost, Fairbanks, Alaska, pp. 1037-1042.
Lewkowicz, A.G., Harris, C., 2005. Morphology and geotechnique of active-layer detachment failures in discontinuous and continuous permafrost, northern Canada. Geomorphology 69, 275-297.

Mackay, J.R., 1959. Glacier ice-thrust features of the Yukon Coast. Geogr. Bull. 13, 5-21.

NASA EOSDIS, 2015. EOSDIS Worldview. [WWW Document]. URL https://earthdata.nasa gov/labs/worldview/ (accessed 12.8.15).

Pautler, B.G., Simpson, A.J., Mcnally, D.J., Lamoureux, S.F., Simpson, M.J., 2010. Arctic permafrost active layer detachments stimulate microbial activity and degradation of soil organic matter. Environ. Sci. Technol. 44, 4076-4082.

Pavlis, N.K., Holmes, S.A., Kenyon, S.C., Factor, J.K., 2008. An Earth Gravitational Model to Degree 2160: EGM2008. EGU General Assembly, pp. 13-18.

Pinchin, B.M., Nairn, R.B., Philpott, K.L., 1985. Beaufort Sea coastal sediment study: numerical estimation of sediment transport and nearshore profile adjustment at coastal sites in the Canadian Beaufort Sea. Geol. Surv. Can. Open-File Rep. 1259, 712.

Ping, C.-L., Michaelson, G.J., Guo, L., Jorgenson, M.T., Kanevskiy, M., Shur, Y., Dou, F., Liang J., 2011. Soil carbon and material fluxes across the eroding Alaska Beaufort Sea coastline. J. Geophys. Res. 116, G02004. http://dx.doi.org/10.1029/2010JG001588.

Rachold, V., Grigoriev, M.N., Are, F.E., Solomon, S., Reimnitz, E., Kassens, H., Antonow, M., 2000. Coastal erosion vs riverine sediment discharge in the Arctic Shelf seas. Int. J. Earth Sci. 89, 450-460.

Rampton, V.N., 1982. Quaternary geology of the Yukon coastal plain. Geol. Surv. Can.

Sadler, P.M., 1981. Sediment accumulation rates and the completeness of stratigraphic sections. J. Geol. 89, 569-584.

Smith, C.A., Kennedy, C., Hargrave, A.E., McKenna, K.M., 1989. Soil and Vegetation of Herschel Island. Research Branch, Agriculture Canada.

Solomon, S.M., 2005. Spatial and temporal variability of shoreline change in the BeaufortMackenzie region, Northwest Territories, Canada. Geo-Mar. Lett. 25, 127-137.

Solomon, S.M., Forbes, D.L., Kierstead, B., 1994. Coastal impacts of climate change: Beaufort Sea erosion study. Geol. Surv. Can.

Vonk, J.E., Sánchez-García, L., van Dongen, B.E., Alling, V., Kosmach, D., Charkin, A. Semiletov, I.P., Dudarev, O.V., Shakhova, N., Roos, P., 2012. Activation of old carbon by erosion of coastal and subsea permafrost in Arctic Siberia. Nature 489, 137-140.

Wahl, H.E., Fraser, D.B., Harvey, R.C., Maxwell, J.B., 1987. Climate of Yukon. Climatological Studies Number 40. Atmospheric Environment Service, Environment Canada, p. 233

White, S.A., Wang, Y., 2003. Utilizing DEMs derived from LIDAR data to analyze morphologic change in the North Carolina coastline. Remote Sens. Environ. 85, 39-47.

Young, A.P., Ashford, S.A., 2006. Application of airborne LIDAR for Seacliff volumetric change and Beach-sediment budget contributions. J. Coast. Res. 307-318 http://dx. doi.org/10.2112/05-0548.1. 